$\stackrel{W}{=}$

Global burnals Inc.

है ?

\title{
Causes and Preventions of Coronavirus (COVID-19)
}

By Tai-Jin Kim

University of Suwon Hwasung

Abstract- Parameter is causing the coronavirus (COVID-19) pandemic was $\mathrm{CO}_{2}$ emissions, correlated with total cases $\left(R^{2}=0.8064\right)$ and deaths $\left(R^{2}=0.7627\right) . \mathrm{CO}_{2}$ emissions produced by coal and gas-powered plants, oil refineries, vehicle, metropolitan food waste gas, human exhalation, leather-tannery industry, and organic dye industry. Cetaceans, including whales, dolphins, and porpoises, transmitted the globe with the coronavirus. The sudden spread of the coronavirus could cause by the 14 habitats of humpback whales, linked to millions of dolphins as well as the global leather tanning industry. It is necessary to monitor the sunspot number to prepare for the effects of cyclic minimum sunspot number in 2031. Because the top 2 countries of $\mathrm{CO}_{2}$ emissions are China and the USA, a new pandemic in 2031 may initiate either from China or from the USA, as H1N1 (the USA, 2009) or as COVID-19 (China, 2020). The preventive phenomena of the third pandemic in 2031 can be monitored at humpback whale districts, as happened in 130 dead dolphins in Cape Verde, at least three months earlier before COVID-19 in China. UV-B radiation is the most efficient method to kill the virus itself.

Keywords: coronavirus (COVID-19), causes, preventions, carbon dioxide emission, tanning leather, dolphin, minimum sunspot number.

GJMR-K Classification: NLMC Code: WC 505

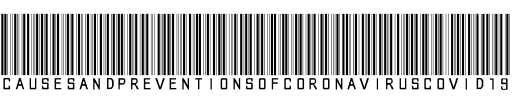

Strictly as per the compliance and regulations of:

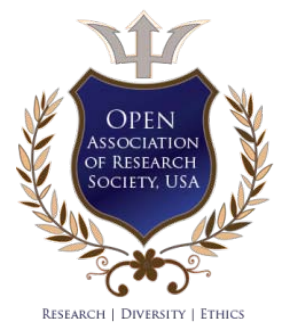

(C) 2020. Tai-Jin Kim. This is a research/review paper, distributed under the terms of the Creative Commons AttributionNoncommercial 3.0 Unported License http://creativecommons.org/licenses/by-nc/3.0/), permitting all non-commercial use, distribution, and reproduction in any medium, provided the original work is properly cited. 


\section{Causes and Preventions of Coronavirus (COVID-19)}

Tai-Jin Kim

Abstract- Parameter is causing the coronavirus (COVID-19) pandemic was $\mathrm{CO}_{2}$ emissions, correlated with total cases $\left(R^{2}=0.8064\right)$ and deaths $\left(R^{2}=0.7627\right) . \quad C O_{2}$ emissions produced by coal and gas-powered plants, oil refineries, vehicle, metropolitan food waste gas, human exhalation, leather-tannery industry, and organic dye industry. Cetaceans, including whales, dolphins, and porpoises, transmitted the globe with the coronavirus. The sudden spread of the coronavirus could cause by the 14 habitats of humpback whales, linked to millions of dolphins as well as the global leather tanning industry. It is necessary to monitor the sunspot number to prepare for the effects of cyclic minimum sunspot number in 2031. Because the top 2 countries of $\mathrm{CO}_{2}$ emissions are China and the USA, a new pandemic in 2031 may initiate either from China or from the USA, as H1N1 (the USA, 2009) or as COVID-19 (China, 2020). The preventive phenomena of the third pandemic in 2031 can be monitored at humpback whale districts, as happened in 130 dead dolphins in Cape Verde, at least three months earlier before COVID-19 in China. UV-B radiation is the most efficient method to kill the virus itself.

Keywords: coronavirus (COVID-19), causes, preventions, carbon dioxide emission, tanning leather, dolphin, minimum sunspot number.

\section{INTRODUCTION}

T here was a sudden increase of the coronavirus (COVID-19) in February of 2020, which turned into a global pandemic. Kim (2019) proposed that the porpoises in the Yangtze River in Wuhan, China, were the initiator of the coronavirus outbreak. The coronavirus (COVID-19) first identified in Wuhan city in Hubei province in China. It postulates that cetaceans, including whales, dolphins, and porpoises, spread the coronavirus around the globe reaching over 213 countries and territories with 6,447,564 total and 380,630 deaths as of June 03 . However, no one has yet proposed the fundamental causes and the protective means except the face mask and social distancing. The present study investigated the principal causes of the coronavirus, along with its preventive means. Parameters investigated are in the areas of leather tanning and processing, oil refineries, gas- and coalpowered plants, total ozone and the ozone hole, skin cancer rate, vehicles, population, carbon dioxide emissions, volcanic regions, migratory birds-humpback whales habitats, dolphins, and preventive means including vaccine development and phenomena for the coming pandemic in 2031.

\section{EXPERIMENT}

\section{a) Hydrogen Sulfide}

Hydrogen sulfide $\left(\mathrm{H}_{2} \mathrm{~S}\right)$ produces during the processes of tannery, leather, footwear, textiles, and garment industries. Decomposed microorganisms in the metropolitan area produce $\mathrm{H}_{2} \mathrm{~S}$. The flue gas in the natural gas or coal-powered power plants, the stack gas in oil refineries, and volcanic gas generate $\mathrm{H}_{2} \mathrm{~S}$. Hydrogen sulfide is very toxic, causing pulmonary disease resulting in death. The effect of $\mathrm{H}_{2} \mathrm{~S}$ compounds upon the growth of phytoplankton experimentally examined as follows. $\mathrm{H}_{2} \mathrm{~S}$ generated by the decomposed white of the egg was prepared to see its removal of iron $(\mathrm{Fe})$ in JM medium with EDTA-Fe as sedimentary iron sulfide (FeS). Fig.1 proved the growth curves of phytoplankton in the $\mathrm{JM}$ medium with various volumes of the decomposed egg solution. Such a phenomenon was due to the addition of the decomposed egg solution producing dissolved hydrogen sulfide $\left(\mathrm{H}_{2} \mathrm{~S}\right)$ to the present JM culture media. It was evident that the phytoplankton growth was retarded when increasing the volume of the decomposed egg solution, generating $\mathrm{H}_{2} \mathrm{~S}$ to remove $\mathrm{Fe}$ from the JM medium with EDTA-Fe as sedimentary iron sulfide (FeS), from $0 \mathrm{ml}, 10 \mathrm{ml}, 30 \mathrm{ml}, 40 \mathrm{ml}$ among total balanced $150 \mathrm{ml} \mathrm{JM}$ culture media. Figure 1 clearly showed that dissolved $\mathrm{H}_{2} \mathrm{~S}$ from the decomposed egg solution reacted with $\mathrm{Fe}$ in the JM media to be Felimited as increasing volumes of the decomposed egg solution. 


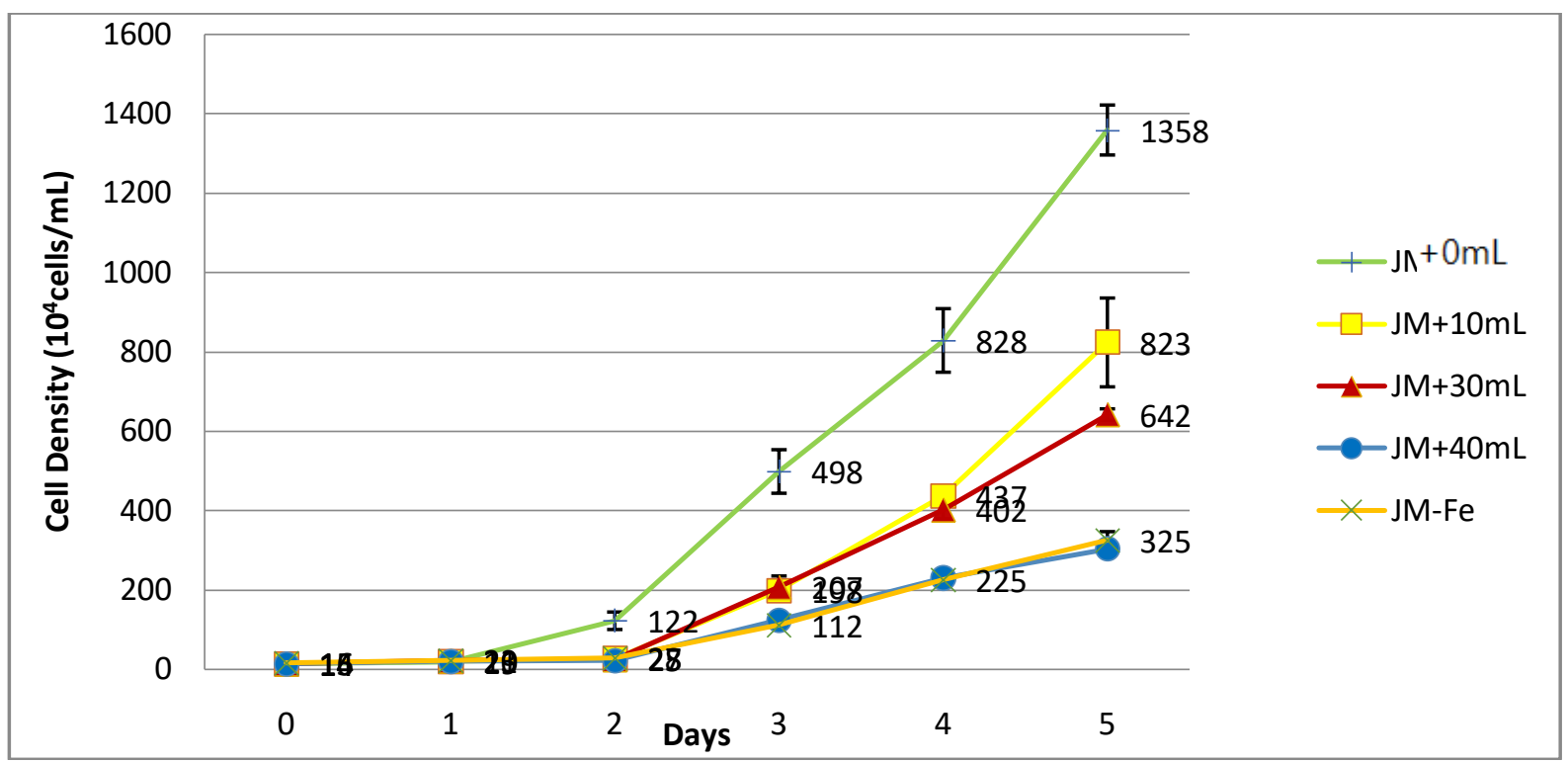

Figure 1: Aerobic culture of Chlorella vulgaris in $\mathrm{JM}$ media with various percent volumes of the decomposed egg solution; with its own Fe and without decomposed egg solution (0\%) (JM+Oml, -+-) for the mixture of $140 \mathrm{ml} \mathrm{JM}$ and $10 \mathrm{ml}$ decomposed egg solution (7\%) (JM+10ml, -- -) for $120 \mathrm{ml} \mathrm{JM}$ and $30 \mathrm{ml}$ decomposed egg solution (21\%) (JM+30ml, - $\mathbf{\Delta}-)$ for $110 \mathrm{ml} \mathrm{JM}$ and $40 \mathrm{ml}$ decomposed solution (28\%) (JM+40ml, -0-), and without its own Fe (JM-Fe, -X-).

\section{b) Iron Fertilization for Reduction of Atmospheric Carbon Dioxide}

Carbon dioxide used by plants in the forestry and the farmland for the photosynthesis of pure oxygen in the sunlight. $71 \%$ of the Earth covers by the oceans containing $40 \%$ diatoms as phytoplankton. Since John Martin proposed the iron hypothesis in 1988, fourteen previous iron enrichment experiments from 1993 to 2012 have conducted in the Southern Ocean, Equatorial Pacific, and Subarctic Pacific. They all failed in selecting an appropriate location for the decrease in atmospheric carbon dioxide concentration. Kim (2020, in press) recently proposed the appropriate location and deployment method for iron fertilization. The decrease in carbon dioxide concentration is important since carbon dioxide emissions increase every year in the Antarctic. Although 14 iron fertilization experiments during the last 27 years have been conducted (KIM, 2020), such experiments have never experimented at a location that is free from serial volcanic eruptions for the removal of volcanogenic sulfur. It recommends that the appropriate iron fertilization experiment be conducted far from sulfur sources such as volcanoes and boundaries of tectonic plates to maximize the availability of dissolved $\mathrm{Fe}$ to phytoplankton for maximal $\mathrm{CO}_{2}$ consumption. The deployment of the Fe-replete composite configures on the streamline of the ACC $(\sim 4 \mathrm{~km} / \mathrm{h})$ to have a high momentum flux for efficient dispersion of Fe-replete composite on the ocean surface where diatom, copepods, krill, and humpback whale stay together $(\sim 100 \mathrm{~m})$. The fast sinking rate of diatom $(0.96 \mathrm{~m} \mathrm{~d}-1)$
(BIENFANG et al., 1984) is very suitable for the sequestration of $\mathrm{CO}_{2}$.

\section{c) Total Ozone and Latitude}

The ozone in the stratosphere absorbs a large part of the Sun's biologically harmful ultraviolet radiation. UV-B radiation (280-315nm wavelength) from the Sun is strongly absorbed. The amount of UV-B radiating on the earth's surface greatly reduces. The values of total ozone are the lowest in the tropics in all seasons because the thickness of the ozone layer is smallest there (www.theozone.com/twenty.htm). There is little variation of the total ozone in the tropics $\left(20^{\circ} \mathrm{N}-20^{\circ} \mathrm{S}\right.$ latitudes), leading to high ultraviolet-B radiation, creating a safe zone from the coronavirus outbreak. Countries are listed below in the rough order of deaths caused by the coronavirus, as of May 2020, with country latitude in parenthesis. 17,983 Brazil (11), 1,242 Indonesia (6), 2,839 Ecuador (2), 2,303 India (21), 5,666 Mexico (19), 842 Philippines (14), 2,914 Peru (10), 441 Dominican Republic (18), 281 Panama (9), 114 Malaysia (3), 56 Thailand (15), 51 Burkina Faso (12), 147 Honduras (15), 61 Democratic Republic of Congo (4), 189 Bolivia (17), 140 Cameroon (6), 55 Niger (18), 10 Mauritius (20), 10 Venezuela (5), 8 Trinidad and Tobago (10), 22 Singapore (1), 192 Nigeria (10), 9 Sri Lanka (7), 50 Kenya (0), 53 Mali (17), 189 Ghana (10), 31 El Salvador (13), 125 Guyana (5), 15 Republic of Congo (0), 23 Liberia (6), 7 Barbados (13), 9 Jamaica (18), 10 Costa Rica (10), 28 Oman (23), 28 Ivory Coast (7), 43 Guatemala (14), 12 Togo (8), 5 Ethiopia (9), 21 Tanzania 
(-7), 4 Zimbabwe (20), 30 Senegal (14), 7 Zambia (-13), 22 Haiti (19), 3 Antigua and Barbuda (17), 3 Angola (12), 111 Sudan (15), 2 Belize (17), 7 Djibouti (11), 1 Brunei (4), 12 Gabon (1).

In contrast, there are countries near to the Artic and the Antarctic Circles that have high skin cancer rates (KIM, 2018) induced by strong UV-B, as listed below with the death cases on the left and the country latitude in parenthesis: 3,743 Sweden (62), 234 Norway (60), 2,942 Russia (60), 301 Finland (64), 10 Iceland (64), 21 New Zealand (-41).

When comparing the two groups of the tropics and Poles, the tropics area has been a safer zone during the coronavirus outbreak. Such a result caused little variation in total ozone throughout the seasons resulting UV-B radiation acting as a shield, leading to the inhibition of coronavirus activity. On the other hand, New Zealand and Iceland have 11 and 136 volcanoes, respectively. Their volcanic fumes inactivate COVID-19 resulting in smaller deaths than other regions.

\section{d) Skin Cancer Rates Leading to Less Coronavirus Cases}

Skin cancer in each country caused by UV-B radiation on the skin. The coronavirus death cases (as of April 14, 2020) in each country were reversely proportional to the skin cancer rates with $R^{2}=0.2098$. Therefore, more coronavirus deaths expect when skin cancer rates are low or, UVB radiation is low. This happened to Italy (ranked $20^{\text {th }}$ in the world of skin cancer rate) with 32,169 deaths, the USA (ranked $17^{\text {th }}$ ) with 93,558 deaths, France (ranked $16^{\text {th }}$ ) with 28,022 deaths, and the UK (ranked 14 ${ }^{\text {th }}$ ) with 35,341 deaths because of the coronavirus, as of May 20, 2020. The prevention of the coronavirus outbreak is possible by increasing UV-B radiation. For long-term projects, it requires to reduce carbon dioxide emissions so that the ozone hole area and UV-B radiation decreases $(\mathrm{NIH}, 1989)$. For shortterm projects, ultraviolet lamps with $280-315 \mathrm{~nm}$ can use to provide UV-B in an indoor space to kill the coronavirus (KIM, 2019). The countries with high skin cancer rates are as follows while coronavirus deaths in parenthesis, as of May 20, 2020.

Australia (100), New Zealand (21), Bolivia (189), Senegal (30), Liberia (23), Gabon (12), Angola (3), South Africa (312), Zambia (7), Norway (234). Australia, Bolivia, South Africa, and Norway had relatively high coronavirus casualties in comparison with other skin cancer rate countries, implying that the coronavirus was strong enough to endure UV-B radiation in the skin cancer countries. Other countries, including New Zealand, much closer to the Antarctic, and African countries in the safe latitude zone, might have enough ozone content to protect people from the coronavirus during UV-radiation. It concludes that the coronavirus (COVID-19) casualties can reduce by proper strength UV-B radiation, which can vary from the low latitude of the equator to the high one of the Poles. For example, the country located at a low latitude country can use low strength UV-B radiators while the middle latitude countries with extremely high casualties can use strong UV-B radiators to protect people from the coronavirus. UV-B ones should be avoided not to directly radiate humans but positioned indirectly not to radiate human eyes and skins.

\section{e) Prevention}

The following locations can act as an asylum from the coronavirus.

\section{i. Tropical Latitude $20^{\circ}$}

Since the ozone concentration is low in the tropical area, and UV-B radiation is strong enough to protect people from the coronavirus.

\section{ii. Active Volcanoes}

Volcanic gases during eruptions contain very toxic components such as $\mathrm{SO}_{2}, \mathrm{CO}, \mathrm{H}_{2} \mathrm{~S}, \mathrm{HCl}, \mathrm{HF}$, and $\mathrm{CO}_{2}$. However, when volcanoes are not in eruptive mode, minor gases are released enough to protect people from the coronavirus activity. Since Indonesia is one of the main manufacturers of leather with its own tanneries, there could be more casualties in Indonesia, even though it locates on the equator with 127 active volcanoes. Japan has 130 active volcanoes and has 146 recorded coronavirus deaths with the $39^{\text {th }}$ global rank. Japan is the $5^{\text {th }}$ most $\mathrm{CO}_{2}$ emissions country and famous for the leather-textile industry, which has led to the coronavirus outbreak. Japan might have fewer cases and casualties due to the presence of volcanoes.

\section{iii. Artificial Volcanic Gases}

The toxic volcanic sulfur gases are $\mathrm{SO}_{2}$ and $\mathrm{H}_{2} \mathrm{~S}$. A small number of such gases can be prepared artificially by heating sulfur (S) powder over burning charcoal to produce $\mathrm{SO}_{2}$ gas. Decomposed food waste produces $\mathrm{H}_{2} \mathrm{~S}$ gas in an ambient condition. Any of these two gases of $\mathrm{SO}_{2}$ and $\mathrm{H}_{2} \mathrm{~S}$ can be spread once a week at a low level of $1 \mathrm{ppm}$ to protect from the coronavirus outbreak.

\section{iv. UV-B Radiation}

UV-B radiation is the most simple, safe, cheap, and efficient method to kill the coronavirus itself. A portable UV-B radiator was used with two 50-Watt UVB lamps in a room while other large sizes 60-watt UVB lamps were used in an office to kill $100 \%$ within 50 minutes (KIM, 2019).

\section{v. Warm and Humid Environment}

The virus is not active at temperatures above $55^{\circ} \mathrm{C}$ and relative humidity of above $40 \%$ (KIM, 2018) with a heater, humidifier, and UV-B radiator installed together to expel the coronavirus.

\section{vi. Curcumin}

India has three major areas for tanneries. India's far lower rate of 3,303 deaths as of May 2020 could be caused by their daily food intake of curcumin. Curcumin has shown to exhibit antioxidant, anti-inflammatory, 
antiviral properties (AGGARWAL et al., 2007), which can help protect against the coronavirus. Consuming Indian curcumin as often as possible is recommended to shield the pulmonary alveolus from the coronavirus attack.

\section{vii. Vegetable Tanning and Natural Chemicals}

Most of the coronavirus outbreak occurred in the 213 countries and territories associated with tannery, leather, footwear, textiles, and garment industries. It spread through human contact in these industries from Wenzhou in China, using toxic chemicals in the tanneryleather process, to Wuhan in China. They emigrated to Milan in Italy and Europe, and eventually to New York City in the USA. However, in Ecuador, one company out

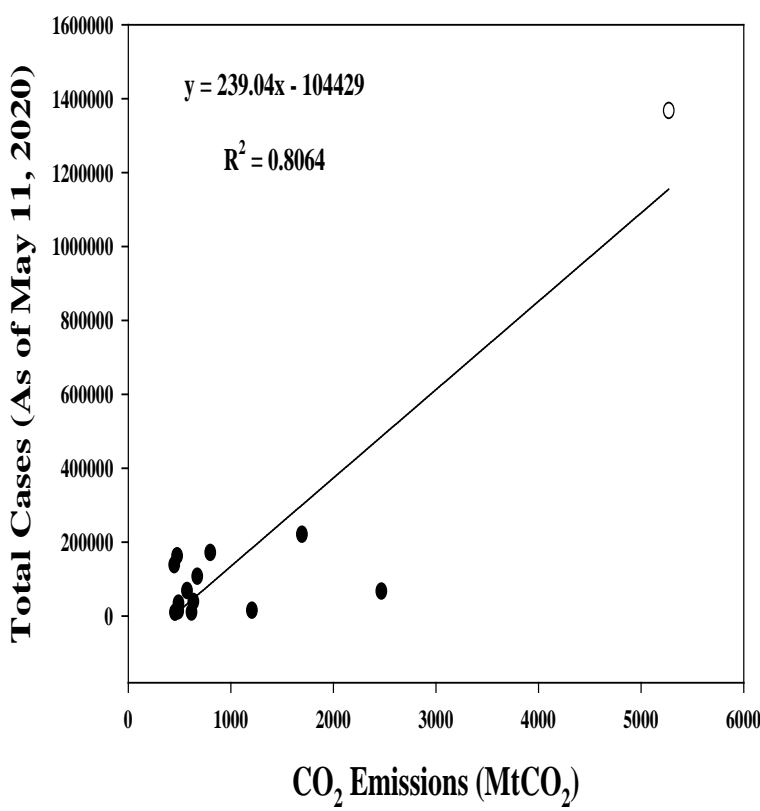

(A) of 50 companies uses natural tanneries without toxic chemicals resulting in no casualties in such an area.

\section{ili. Causes}

a) Carbon Dioxide $\left(\mathrm{CO}_{2}\right)$

$\mathrm{CO}_{2}$ emissions in Fig. 2 commonly produced by coal- and gas-powered power plants, oil refineries, vehicle exhaust gas, metropolitan food waste gas, human respiration, the leather-tannery industry, and the dye industry. On the other hand, $\mathrm{CO}_{2}$ can be consumed by the forest and the farmland while most of the decrease can accomplish by the iron fertilization, initiated by John Martin in 1988 (KIM, 2020 in press).

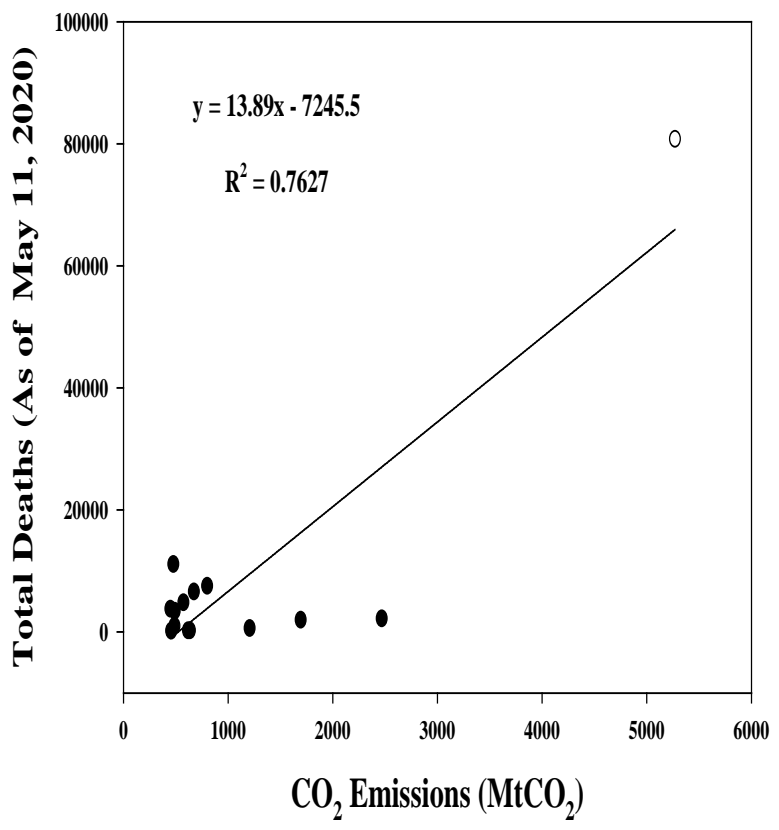

(B)

Figure 2: Global $\mathrm{CO}_{2}$ emissions with $(A)$ the total cases $\left(\mathrm{R}^{2}=0.8064\right)$ and (B) deaths $\left(R^{2}=0.7627\right)$, as of May 11,2020

Global $\mathrm{CO}_{2}$ emissions in metric tons correlated with the total cases $\left(R^{2}=0.8064\right)$ and deaths $\left(\mathrm{R}^{2}=0.7627\right)$ in Fig. 2. European $\mathrm{CO}_{2}$ emissions correlated with total cases $\left(R^{2}=0.6142\right)$ and with deaths $\left(R^{2}=0.4763\right)$. USA State $\mathrm{CO}_{2}$ emissions correlated with total cases $\left(R^{2}=0.6065\right)$ and with deaths $\left(R^{2}=0.4401\right)$. USA State oil refinery capacity producing $\mathrm{CO}_{2}$ gases in stack gas correlated with total cases $\left(R^{2}=0.4003\right)$ and with deaths $\left(R^{2}=0.6413\right)$. The global vehicle number producing $\mathrm{CO}_{2}$ exhaust gases correlated with total cases $\left(R^{2}=0.6068\right)$ and with deaths $\left(R^{2}=0.6313\right)$. Global population number producing $\mathrm{CO}_{2}$ gases as human exhaling gas correlated with total cases $\left(R^{2}=0.6373\right)$ and with deaths $\left(R^{2}=0.4642\right) . \quad \mathrm{CO}_{2}$ emissions from various sources have increased UV-B radiation on the earth (KIM, 2019). Global rankings for $\mathrm{CO}_{2}$ emissions in 2017 is listed below with the rank of coronavirus cases as of May 7, 2020 in -number: China (9,838 metric tons) -13, USA $(5,270)-1$, India $(2,467)$ - 11, Russian Federation $(1,693)-2$, Japan $(1,205)-39$, Germany $(799)$ -8, Iran (672) -10, Saudi Arabia (635) -15, South Korea (616) -45, Canada (573) -14, Brazil (500) -4, Mexico (490) -17, Indonesia (487) -33, South Africa (456) -36, Turkey (448) -9, Australia (413) -54, United Kingdom (385) -5, France (356) -5, Italy (355) -6, Thailand (331) 70, Poland (327) -31, Kazakhstan (293) -57. A detailed analysis of the above statistical data can be summarized for these countries as follows:

1. China is supposed to be ranked first for coronavirus cases accounting for its being the country of origin of the coronavirus and having the largest population. Their coronavirus data seems to be inaccurate. 
2. The USA has the highest total coronavirus deaths in the world. They have a little tannery-leather industry polluting rivers and lakes. Cetaceans and migratory birds transmitted the coronavirus. Power plants (coal and gas- powered) and oil refineries produced toxic gases $\left(\mathrm{SO}_{2}, \mathrm{H}_{2} \mathrm{~S}\right)$, which are very harmful to the pulmonary disease elderly with the coronavirus attacking the lungs directly, inducing pneumonia.

3. India is supposed to be high in coronavirus cases so far as its active tannery-leather industry and having the largest oil refinery in the world. Favorable parameters are Indian latitude location $\left(8-37^{\circ} \mathrm{N}\right)$ with a safe zone within 20 degrees for the coronavirus. Most Indians eat curry containing curcumin, which provides anti-inflammatory benefits. It is beneficial since the coronavirus inflames the lungs and results in the air sacs filling with pus (ELDRIDGE, 2019). India's favorite food being curry could have saved the nation from the coronavirus.

4. Japan has much lower casualties than would be supposed. Their 129 volcanoes could have partly blocked the coronavirus cases.

5. South Korea had a relatively low level of coronavirus cases. $70 \%$ of land of South Korea is covered by mountains as well as having four large rivers with no water pollution. Oil refineries are spread over the country and located on the coast to disperse the toxic stack gases to the sea atmosphere. Most importantly, Koreans wore face masks for protection from the coronavirus. The terribly contaminated location was Daegu city, where the textile coloring with toxic chemicals has made for many years in a designated complex. Such wastewater effluents contain toxic organic dyes and caustic soda, deteriorating the rivers and eco-system, which was why Korea was in the top ranks until March.

6. Indonesia has 127 active volcanoes whose latitude is $6^{\circ} \mathrm{N}$. These two positive factors could have saved Indonesia from the coronavirus. Indonesia has negative factors such as tannery-leather production, oil refineries, population, vehicles, and power plants.

7. South Africa and Australia locate at the boundary of the Antarctic ozone hole, where UV-B radiation is strong enough to protect from the coronavirus.

8. The United Kingdom (5), France (7), Italy (6) more highly ranked in total cases as of May 20, 2020, than expected by $\mathrm{CO}_{2}$ emissions of (17), (18),(19), respectively, which could additionally caused by the tannery-leather industry and dolphins in each country.

9. Thailand, Poland, and Kazakhstan showed agricultural lands of $43 \%, 47 \%$, and $80 \%$ in 2016 , respectively. Since agricultural land converts harmful air $\mathrm{CO}_{2}$ to good air $\mathrm{O}_{2}$ (oxygen) as fresh air, the coronavirus activity inhibits, resulting in much lower coronavirus casualties under low $\mathrm{CO}_{2}$ and thus high UV-B radiation. It is essential to increase the portions of agricultural land and forestry, especially in New York City and other metropolitan cities (Milan, Washington D.C., Paris, London, Tehran, Istanbul, Tokyo, Beijing, and Daegu).

\section{b) The Ozone Hole}

The ozone is a gas that forms a naturally occurring layer in the stratosphere, protecting the Earth from the Sun's ultraviolet (UV) light. The ozone hole over Antarctica is affected in Argentina (393 deaths from coronavirus, as of May 20, 2020), Chile (509), South Africa (312), New Zealand (21), and Australia (100), which were relatively low compared to other countries. There is excessive UV-B radiation in the tropical area, while the large ozone holes in the Polar areas have excessive UV-B radiation. In the middle latitude area, UV-B radiation is not strong enough to inhibit the activity of the coronavirus. Global ranking of coronavirus cases with latitude as follows: USA $38^{\circ} \mathrm{N}$, Spain $40^{\circ} \mathrm{N}$, Italy $43^{\circ} \mathrm{N}$, France $47^{\circ} \mathrm{N}$, Germany $52^{\circ} \mathrm{N}$, UK $54^{\circ} \mathrm{N}$, Turkey $41^{\circ} \mathrm{N}$, Iran $36^{\circ} \mathrm{N}$, Russia $60^{\circ} \mathrm{N}$, China $35^{\circ} \mathrm{N}$, Canada $56^{\circ} \mathrm{N}$, Belgium $51^{\circ} \mathrm{N}$, Netherlands $52^{\circ} \mathrm{N}$, Switzerland $47^{\circ} \mathrm{N}$, Portugal $39^{\circ} \mathrm{N}$, Ireland $33^{\circ} \mathrm{N}$, Sweden $62^{\circ} \mathrm{N}$, Saudi Arabia $24^{\circ} \mathrm{N}$, Israel $31^{\circ} \mathrm{N}$, Austria $47^{\circ} \mathrm{N}$, Mexico $39^{\circ} \mathrm{N}$, Japan $36^{\circ} \mathrm{N}$, Chile $30^{\circ} \mathrm{S}$, Pakistan $30^{\circ} \mathrm{N}$, Poland $52^{\circ} \mathrm{N}$, Romania $46^{\circ} \mathrm{N}$, Belarus $53^{\circ} \mathrm{N}, \mathrm{S}$. Korea $37^{\circ} \mathrm{N}$, UAE $25^{\circ} \mathrm{N}$, Qatar $25^{\circ} \mathrm{N}$, Ukraine $48^{\circ} \mathrm{N}$, Denmark $56^{\circ} \mathrm{N}$, Serbia $44^{\circ} \mathrm{N}$, Norway $60^{\circ} \mathrm{N}$, Czechia $49^{\circ} \mathrm{N}$, Argentina $35^{\circ} \mathrm{S}$. Various latitudes lead to different ozone concentrations affecting the strength of UV-B radiation. Therefore, there were coronavirus cases with fewer casualties in the tropical areas and in the Poles.

There is a question as to why the coronavirus occurred in Wuhan city in Hubei province, China. Why not anywhere else? Chinese foam manufacturers released ozone-destroying chemicalchlorofluorocarbons (CFC-11) used in refrigerators and air-conditioners (RIGBY et al., 2019). China produced the highest carbon dioxide emissions in the world (9.8 billion metric tons in 2017). Besides, China used to use banned ozone-depleting chemicals of CFC-11. Industrialized Wuhan, with 11 million people, is the capital of Hubei province with polluted water and air, generating a mutant virus under excessive UV-B radiation during the minimum sunspot number. The simultaneous conditions of the ozone hole increased as well as harmful UV-B radiation during the minimal sunspot number, induced the potent mutation of the evolutionary virus in the form of the coronavirus (COVID19) in Wuhan in China.

\section{c) Sunspot Number}

Solar flare (sunspots) with an 11-year cycle alter the amount of ultraviolet radiation (UVR) reaching the Earth. Solar flares increase ozone concentration in the stratosphere (above 50km), thereby absorbing the amount of surface UVB, which is known to cause skin cancer and suppress the immune system. The thinning 
of the ozone layer (about $3 \mathrm{~mm}$ in thickness) over Antarctica was caused by ozone depleting chemicals of CFCs in eastern China (RIGBY et al., 2019). When solar flares are inactive and minimal, there is a decrease in the ozone concentration, allowing increased UVB to penetrate to the Earth's surface $(\mathrm{NIH}, 1989)$. Fig. 3 showed that the sunspot number from 1979 to 2019 was reversely proportional to the ozone hole area (million $\mathrm{km}^{2}$ ) with $\mathrm{R}^{2}=0.2668$.

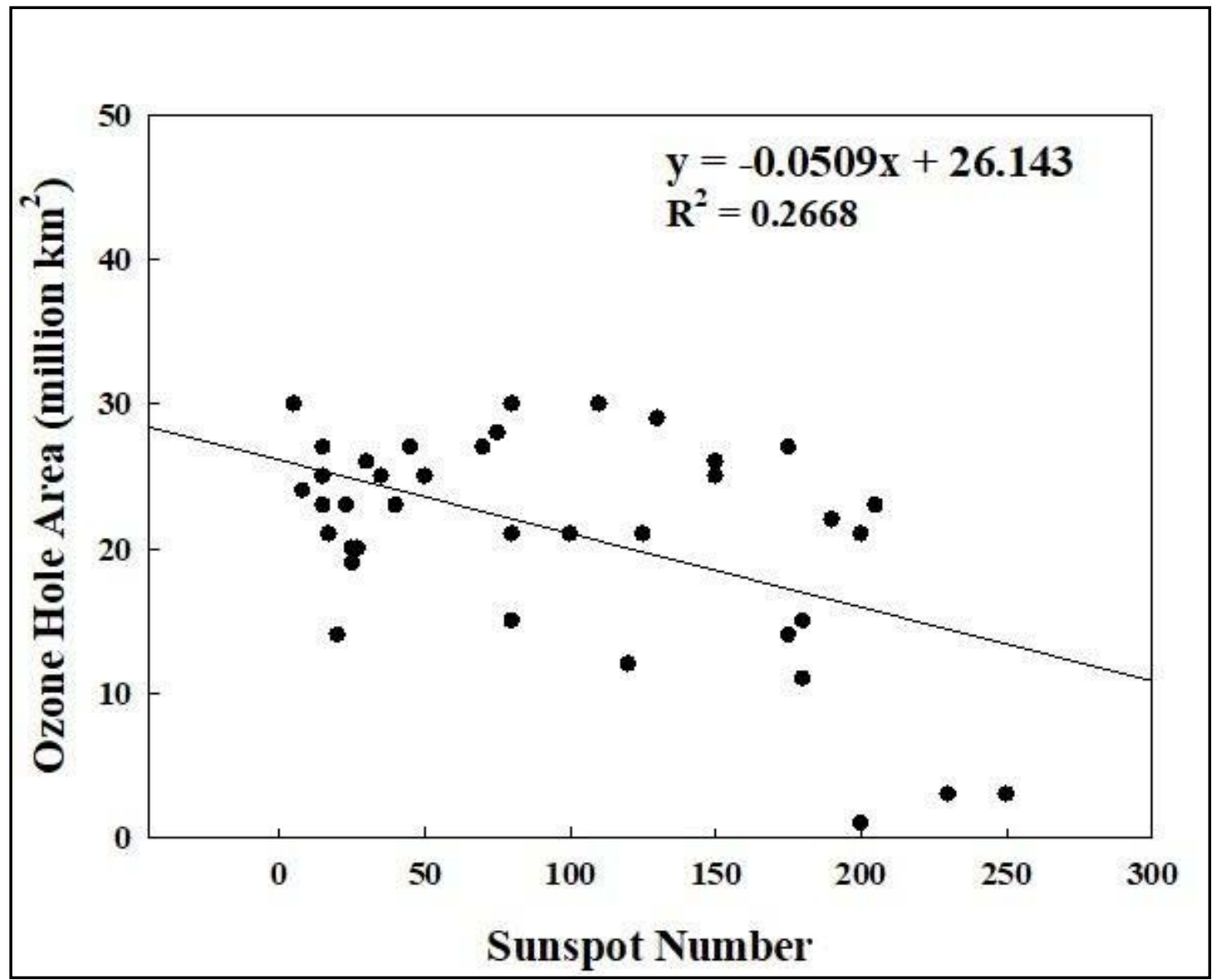

Figure 3: Sunspot numbers from 1979 to 2019 correlated with the ozone hole area (million $\mathrm{km}^{2}$ ) with $\mathrm{R}^{2}=0.2668$

The minimum sunspot number induced a high ozone hole area, leading to high $\mathrm{CO}_{2}$ emissions (KIM, 2019). A significant viral mutation was therefore occurred in the period of the minimum sunspot number in a location with the highest $\mathrm{CO}_{2}$ emissions and ozone hole areas, which was the case of the COVID-19 outbreak from 2019 to the present day in the metropolitan Wuhan of China as well as in other large cities, including New York City, Madrid, Paris, London, Milan, Bavaria, Istanbul, Tehran, Tokyo, and 213 countries and territories.

The number reached the minimum sunspot number from 2019 (sunspot number 0.8) to 2020 (6.0). The solar UV-B becomes excessive for the activation of the coronavirus, especially in the middle latitude countries with less total ozone content than the tropical or Polar countries. The ozone hole is big in the Antarctic while it is small in the Arctic. As a consequence, New Zealand, which locates near to the Antarctic, was hit weaker by the coronavirus pandemic than Sweden, which is near to the Arctic. It is, therefore necessary to monitor the sunspot number, especially when approaching the period of minimum sunspot number, to prepare for the effects of another cyclic minimum sunspot number in 2031.

\section{d) Cyclic Emergence of Harmful Viruses}

Human coronavirus compared to their significant virus in chronic order with deaths in parenthesis are as follows (BAKER et al., 2020). In 1976 identified Ebola (13,562 deaths) plus 11 years later, H1N1 AIV in 1988 plus 10 years later, Nipah in 1998 (398) plus 11 years later, the first pandemic in 2009 $\mathrm{H} 1 \mathrm{~N} 1$ swine virus mutated to infect humans and spread by humans $(284,000)$ plus 11 years later, the second pandemic in 2020 coronavirus (COVID-19) humans $(380,630$ deaths as of June 03). These viruses have occurred either during the maximum sunspot number (SARS, 774 deaths in 2002 and MERS, 858 deaths in 2012) or during the minimum sunspot number (Ebola, Nipah, AIVs, COVID-19). The sunspot number has an 11-year cycle plus 14 months standard deviation 
(HATAWAY, 2010). If assuming 12 years as one cycle, every six years provide the maximum or the minimum points. During the minimum sunspot number and the highest $\mathrm{CO}_{2}$ emissions, as is in 2020 with the coronavirus (COVID-19) pandemic, the ozone hole area is increased causing the potent UV-B radiation on the Earth $(\mathrm{NIH}, 1989)$ for the active virus mutant in the form of the coronavirus (COVID-19) pandemic with terribly high casualties in 213 countries and territories. It expects that disastrous outbreaks of viruses occur in 2020 plus 11 years later of, 2031 as the third pandemic via either humans, birds, cetaceans, pigs, or other species. Cetaceans such as humpback whale/dolphin/porpoise were proposed as the transmitters of MERS-CoV stranded humpback whales in the Persian Gulf coast in Saudi Arabia (KIM, 2019) as well as of the coronavirus (COVID-19) stranded porpoises in the Yangtze River in China (KIM, 2019), respectively. The ultimate causes of the coronavirus for future viruses are $\mathrm{CO}_{2}$ emissions. Therefore, all countries that were hit by the coronavirus (COVID-19) should reduce their $\mathrm{CO}_{2}$ emissions from the leather-tannerytextile garment industry, oil refineries, gas, and coalpowered plants, vehicle exhaust, metropolitan food waste biogas for clean water and air with less toxic chemicals on the Earth.

\section{e) Migratory Birds and Humpback Whales Habitats}

Humpback whales feed on krill and small fish in

Antarctica and Arctica while migrating to tropical or subtropical waters during the winter breeding in Northern and Southern Hemispheres, as shown in Fig. 4.

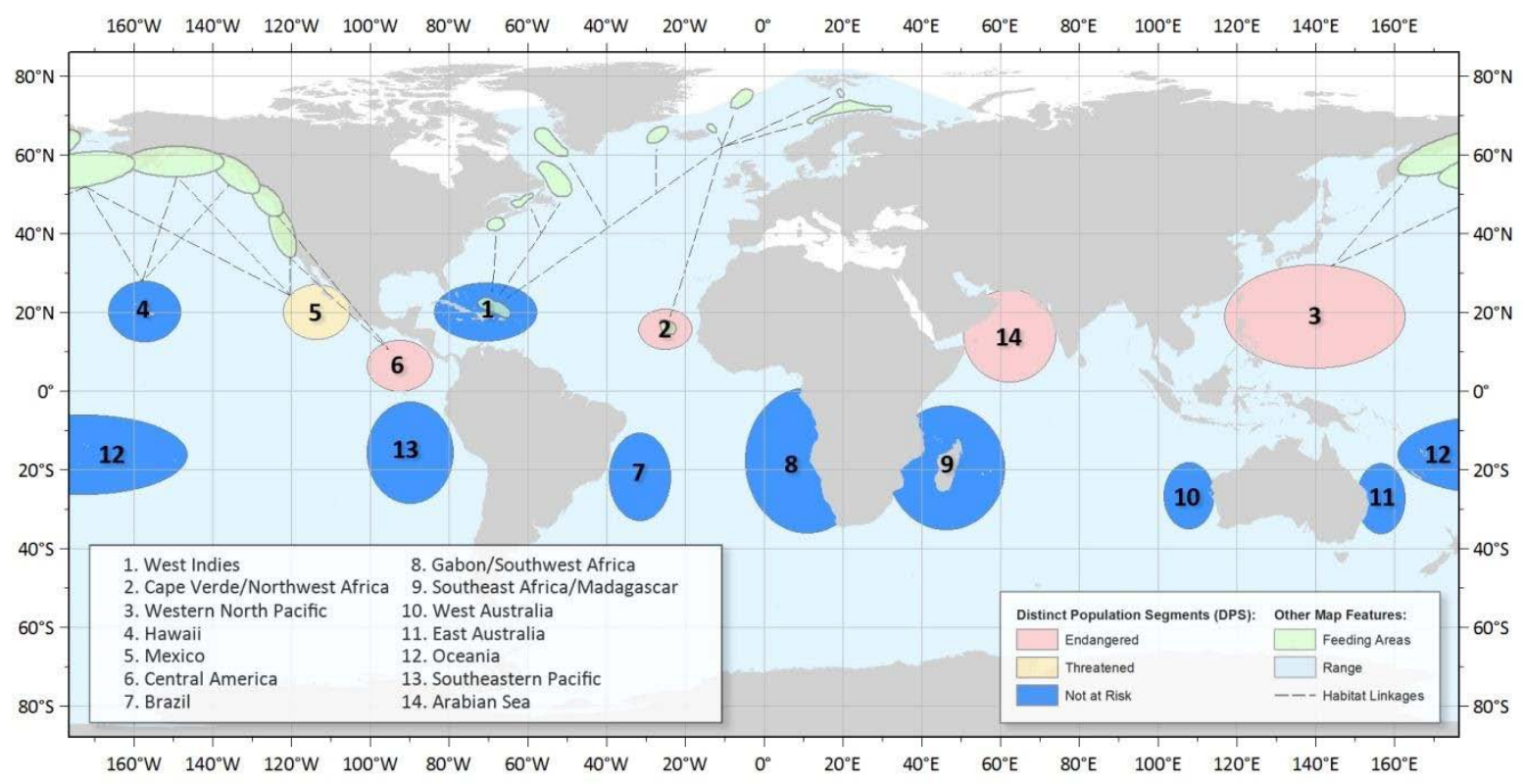

Figure 4: The distribution of 14 identified humpback whale district population segments is for the breeding zone from December to April while the feeding zone in the Arctic and the Antarctic during the winter (NOAA, 2015)

Mutant viruses persisting in host cells of aquatic bacteria are food web prey of algae, krill, small fish, squid, and finally penguin and humpback whales. It is interesting to note that marine mammals such as harbor seals, elephant seals, and pilot whales were infected by evolutionary AIV near the habitats of the coastal line (YOON et al., 2014) while the humpback whale prefers to stay at the coast less than $50 \mathrm{~m}$ underwater. Since penguins are birds while humpback whales are marine mammals, their strains of AIV cannot be the same. Therefore, marine mammals with AIV such as harbor seals (H3N3, H3N8, H4N5, H4N6, H7N7), elephant seals (H1N1), and pilot whales $(\mathrm{H} 3, \mathrm{H} 4, \mathrm{H} 7, \mathrm{H} 13)$ could directly infect by humpback whale feces and indirectly transmit by wild aquatic birds. There are aquatic food web cycles from viruses, bacteria, phytoplankton, zooplankton, krill, small fish, squid, penguin, and humpback whale. Therefore, if there is the germicidal UV radiation during the $\mathrm{CO}_{2}$ emission increase and the minimal sunspot number period, the aquatic virus is mutated.

Consequently, penguins and humpback whales are easily infected by mutant AIV through food web cycles. It can postulate that mutant krill are the main reservoir of AIV whose mutant virus, induced by the germicidal UV-B radiation during the 11-year periodic minimal sunspot number are transmitted from penguins in Antarctica and guillemot in Arctica to Continents by migratory birds with AIV (KIM, 2018) and humpback whales with cetacean morbillivirus (CMV) (KIM, 2019). 
Mixed mutant virus was in the form of the coronavirus (COVID-19) in Wuhan in China (KIM, 2019) to be retrospectively transmitted to cetaceans (porpoises, dolphins, whales) and humans in 2020. Fig. 5 shows that migratory flyways of wild birds overlap with the routes of humpback whales (14 habitats in Fig. 4) to suggest that AIV may transmit, not only by commonly known migratory birds flyways but also by humpback whales habitats (KIM, 2018).

\section{Black Sea/Mediterranean Flyway}

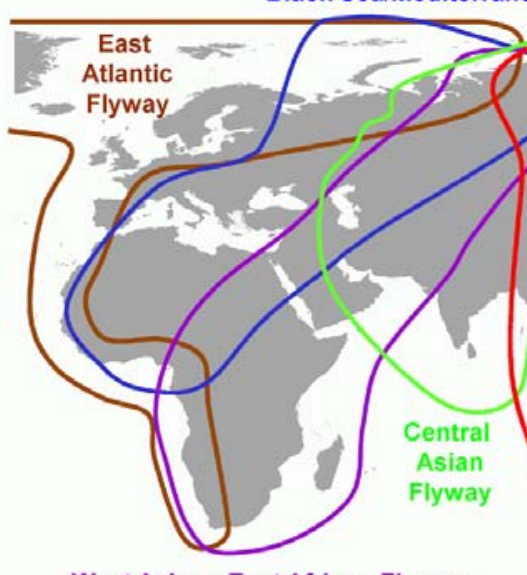

West Asian - East African Flyway

O EAAFP Secretariat

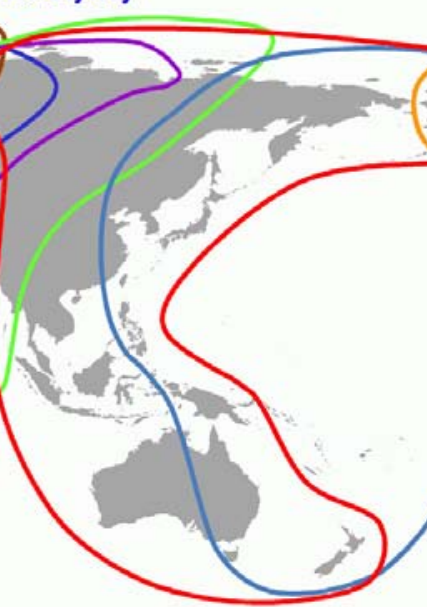

East Asian - Australasian Flyway
Mississippi Americas Flyway

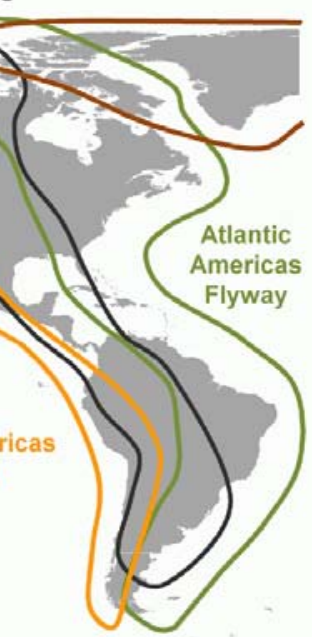

Figure 5: Migratory flyways of wild bird populations with corresponding numbers of humpback whale habitats in Fig. 4 to indicate similar routes between migratory birds and humpback whales

\section{f) Transmission of Coronavirus}

There were sudden increases in global coronavirus cases since February of 2020. It postulates that cetaceans, including whales, dolphins, and porpoises, surround the globe with the coronavirus disaster in over 213 countries and territories. Transmissions of coronavirus (COVID-19) from the aquatic virus mutant in the Poles through infected migratory humpback whales to coastal animals and humans, were pictorially described in Fig. 6. 


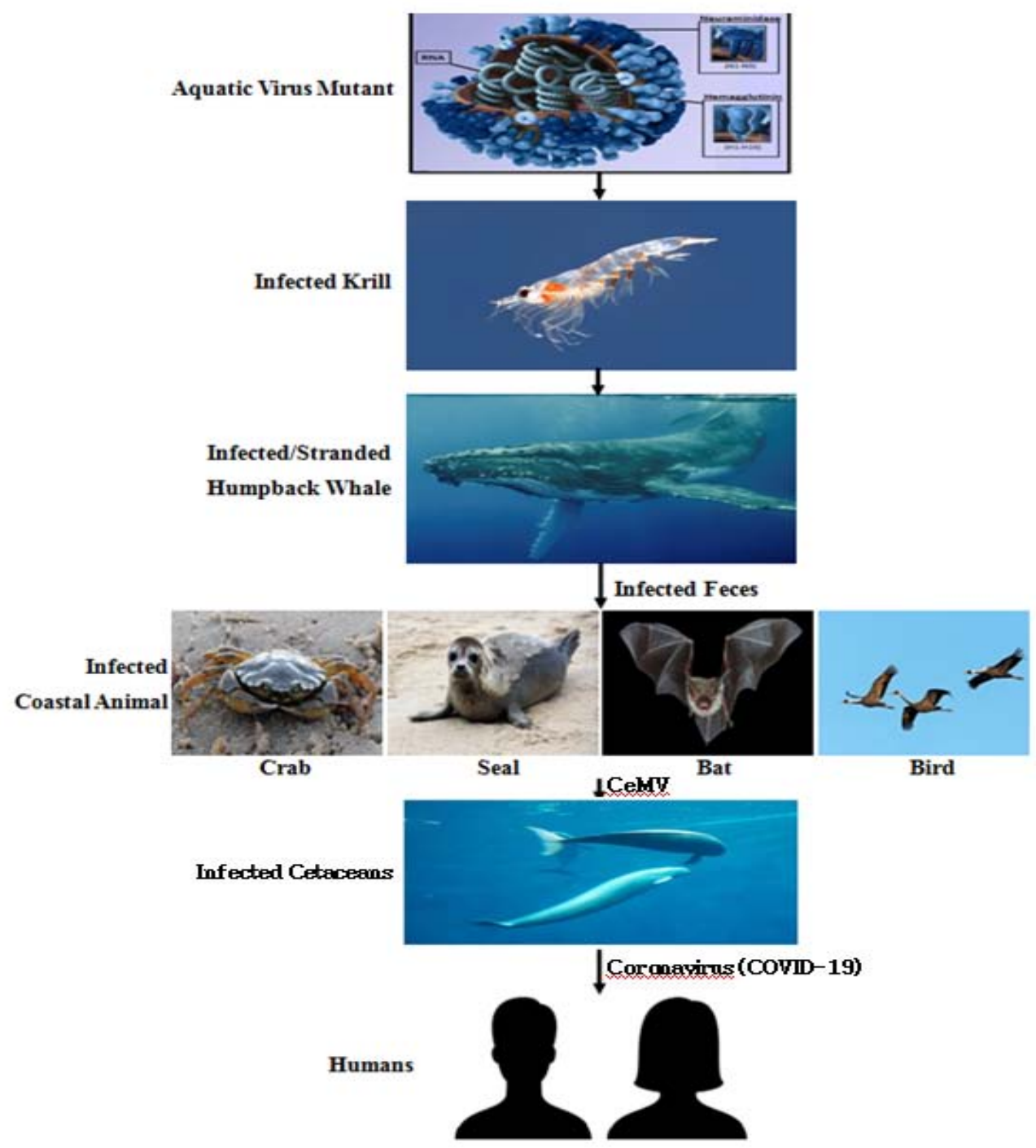

Figure 6: Pictorial presentation for transmissions of the coronavirus (COVID-19) from the aquatic virus mutant through infected migratory humpback whales to coastal animals (crab, seal, bat, bird, porpoise, dolphin, whale) and humans

\section{g) Dolphins}

Since humpback whales feed on the krill infected by the mutant aquatic virus and small fish, infected humpback whales might be the reservoir of the $\mathrm{CMV}$ in the form of infected feces from the Poles to Continents through their regular migratory behaviors in Fig. 4. Released feces infected porpoises and dolphins in the 14 districts in Fig. 4, including the Yangtze River and East Sea (Site 3 among 14 in Fig. 4) to be evolutionally transmitted to humans in Wuhan of China as the COVID-19 (KIM, 2019). Bottlenose dolphins are found in almost every ocean and sea, other than the coldest waters toward /the Poles (wwhandbook.iwc.int/ en/species/bottle.), as shown in Fig. 7. Bottlenose dolphins in the United States are protected under the marine mammal protection act. Bottlenose dolphins find in temperate and tropical waters around the world. They are also found in coastal and offshore waters along the East Coast from New York to Florida, throughout the Gulf of Mexico, and in the Caribbean (www.fisheries. noaa.gov/species/comm.,). The worldwide population of common dolphins is about 600,000. The global estimated population size of the striped dolphin is over 2 million, while the short-beaked common dolphin is estimated to number around 4 million. There are 80,000 humpback whales. Striped dolphins have been the victims of several mass die-offs caused by a virus called morbillivirus, which induced as cetacean morbillivirus (CMV) due to high levels of contaminants and other environmental factors. Kim (2019) proposed that CMV is the source of the COVID-19 initiated by the highest $\mathrm{CO}_{2}$ emissions, polluted water, and air in Wuhan in China during the minimum sunspot number, which maximized the virus mutation capability under the germicidal UV-B 
radiation. Since dolphins swim in shallow areas less than 25 feet, it advises not to go to the beach since air infection by CMV infected dolphins can be transmitted to people, as is the case with the coronavirus. Fig. 7 shows that dolphins are spread all around the world except Poles. Common bottlenose dolphins (wwhandbook.iwc.int/en/ species/bottle.) occur in all almost tropical and temperate regions, and can find in both coastal and offshore (wwhandbook.iwc.int/ en/species/bottle.) waters. They are found in most enclosed or semi-enclosed seas (e.g. North Sea, Mediterranean, Black Sea, Persian Gulf), and bays, lagoons, channels and river (wwhandbook.iwc.int /en/species/bottle.) mouths. Indo-Pacific bottlenose dolphins have a more restricted range with boundaries at the southern tip of Africa to the west, and the Solomon Islands/ New Caledonia to the east. They are generally limited to coastal and inshore waters on the continental shelf, although they are also found around some Indo-Pacific island (wwhandbook. iwc.int/en/species/bottle.) groups. Common Bottlenose dolphins are native to the following countries: Albania;
Algeria American Samoa; Angola /Anguilla Antigua and Barbuda; Argentina, Aruba; Australia; Bahamas; Bahrain; Bangladesh; Barbados; Belgium; Belize; Benin; Bermuda; Bonaire, Sint Eustatius and Saba (Saba, Sint Eustatius); Bosnia and Herzegovina; Brazil; Brunei Darussalam; Bulgaria; Cambodia; Cameroon; Canada; Cape Verde; Cayman Islands; Chile; (wwhandbook.iwc. int/en/species/bottle.) Cocos (Keeling) Islands; Colombia Comoros; Cook Islands; Costa Rica; Cote d'ivoire; Croatia; Cuba; Curacao; Cyprus; Denmark; Djibouti ; Dominica; Dominican Republic; Ecuador; Egypt; El Salvador; Falkland islands (Malvinas); Faroe Islands; Fiji; France; French Guinea; French Polynesia; Gabon; Gambia; Georgia; Germany; Ghana; Gibraltar; Greece; Grenada; Guadeloupe; Guam; Guatemala; Guernsey; Guinea; Guinea-Bissau, Guyana; Haiti; Honduras; Hong Kong; India; Indonesia; Iran, Islamic Republic of; Ireland; Isle of Man; Israel; Italy; Jamaica; Japan; Jersey; Kenya; Kiribati; Korea, Republic of; Kuwait;; Lebanon; Liberia; Libya, Madagascar, Malaysia, Maldives, Malta (wwhandbook.iwc.int/en/ species/bottle.),

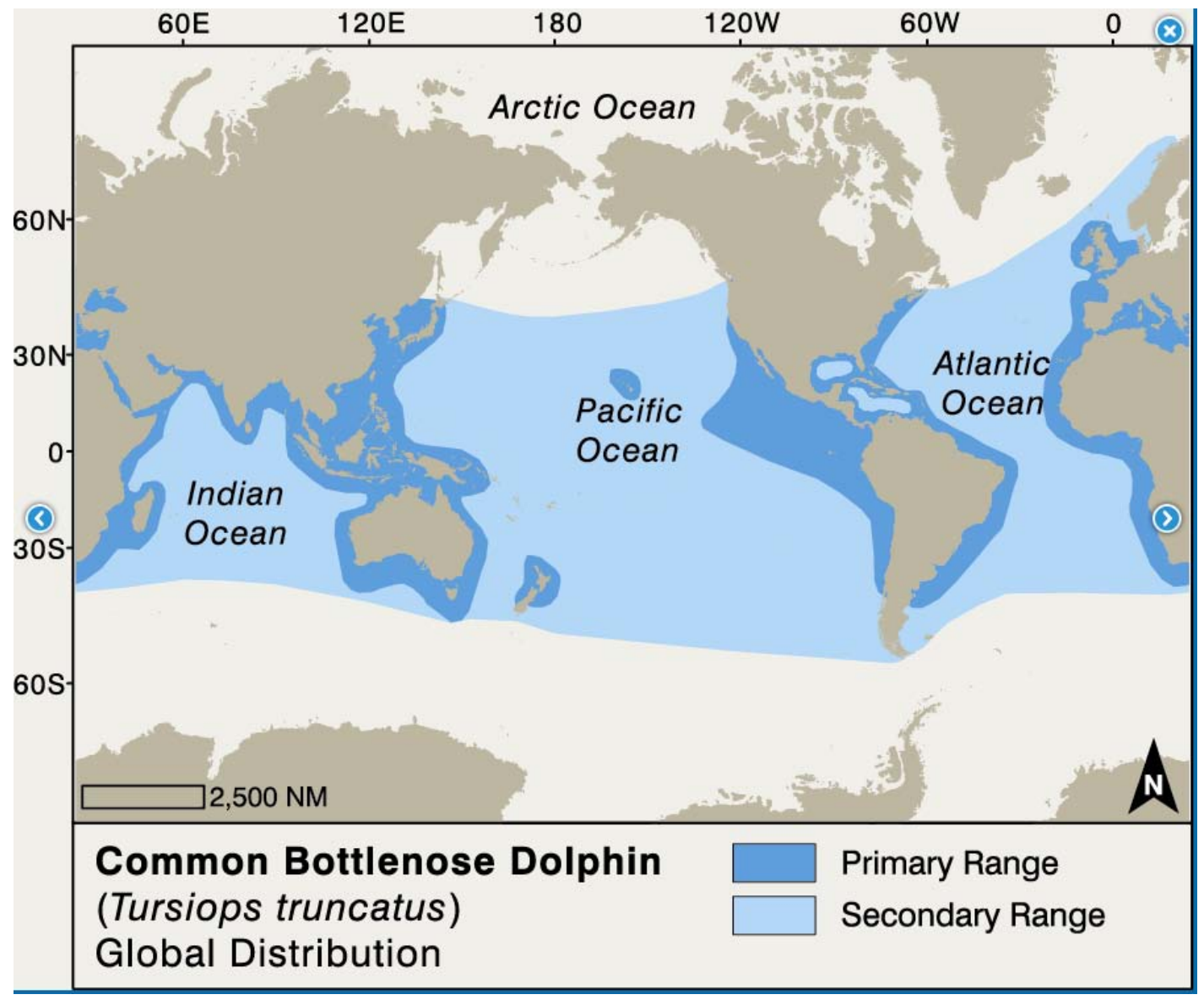

Figure 7: Known range of bottlenose dolphins are indicated in dark blue (JEFFERSON et al., 2015)

Marshall Islands; Martinique; Mauritania; Mayotte; Mexico; Micronesia, Federated States of; Monaco; Montenegro; Morocco; Mozambique; Myanmar; Namibia; Naurus; Netherlands; New
Caledonia; New Zealand; Nicaragua; Nigeria, Niue; Northern Mariana Islands; Oman; Pakistan; Palau; Panama; Papa New Guinea; Peru; Philippines; Pitcairn; Portugal; Puerto Rico; Qatar; Reunion; Romania; 
Russian Federation; Saint Helena; Ascension and Tristan da Cunha; Saint Kitts and Nevis; Saint Lucia; Saint Martin (French part; Saint Pierre and Miquelon; Saint Vincent and the Grenadines; Samoa; Sao Tome and Principe; Saudi Arabia; Senegal; Seychelles; Singapore; Sint Maarten (Dutch part); Slovenia; Solomon Islands; Somalia; South Africa; Spain; Sri Lanka; Suriname; Syrian Arab Republic; Taiwan; Tanzania, United Republic of, Thailand; Togo; Tonga; Trinidad and Tobago; Tunisia, Turkey; Turks and Caicos Islands; Ukraine; United Arab Emirates; United Kingdom; Uruguay; Vanuatu, Venezuela, Bolivarian Republic of (wwhandbook.iwc.int /en/species/bottle.); Vietnam, United States; Wallis and Futuna; Western Sahara; Yemen. Indo-Pacific humpback dolphins are native to Australia; Bahrain; Bangladesh; Brunei Darussalam; Cambodia; China; Comoros; Egypt; Eritrea; India; Indonesia; Iran, Islamic Republic of; Japan; Kenya; Madagascar; Malaysia; Mayotte; Mozambique; Myanmar; Oman; Pakistan; Papua New Guinea; Philippines; Saudi Arabia; Singapore; Solomon Islands; Somalia; South Africa; Sri Lanka; Taiwan, Province of China; Tanzania, the United Republic of; Thailand; Timor-Leste; United Arab Emirates; Yemen (wwhandbook.iwc.int/en/species/ bottle.).

Dolphins cover most of the seawater in the world, as shown in Fig. 7, which agrees well with results

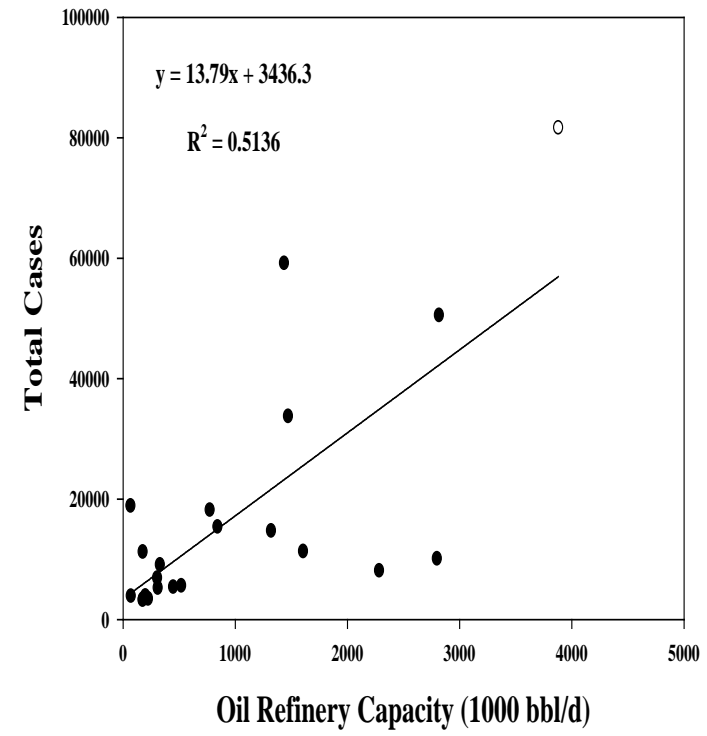

(A) that there were sudden increases in global coronavirus cases since February of 2020. It postulates that cetaceans, including whales (Fig. 4), dolphins (Fig. 7), and porpoises transmit the globe with the coronavirus (COVID-19) pandemic in over 213 countries and territories (Fig. 14 B).

\section{h) Oil Refineries and Power Plants}

Refining involves reducing sulfur to form $\mathrm{H}_{2} \mathrm{~S}$ while kerosene, butane, and propane are washed in a caustic soda. It expects that petroleum refineries cause water pollution by cooling water as well as the air pollution by stack gas, which was why coronavirus cases were proportional to oil refinery capacity in Fig. 8.

Total coronavirus cases by country, as of April 3, 2020, were linearly proportional to oil refinery capacity as $R^{2}=$ 0.5136 for the total cases and $R^{2}=0.4874$ for the deaths, respectively. Stack gases from petroleum refineries are toxic gases $\left(\mathrm{CO}_{2}, \mathrm{SO}_{2}, \mathrm{O}_{3}, \mathrm{H}_{2} \mathrm{~S}\right.$, NOx) burnt at stack to be less harmful. $91 \%$ of water requirements were for cooling for 95\% makeup-water requirements with impurities of $\mathrm{H}_{2} \mathrm{~S}, \mathrm{CO}_{2}, \mathrm{O}_{2}$, suspended solids, sulfate, silica and other corrosive chemicals (OTTS 1963). These pollutants cause both air pollution and water pollution for the coronavirus outbreak due to enhanced $\mathrm{CO}_{2}$ emissions for the active COVID-19.

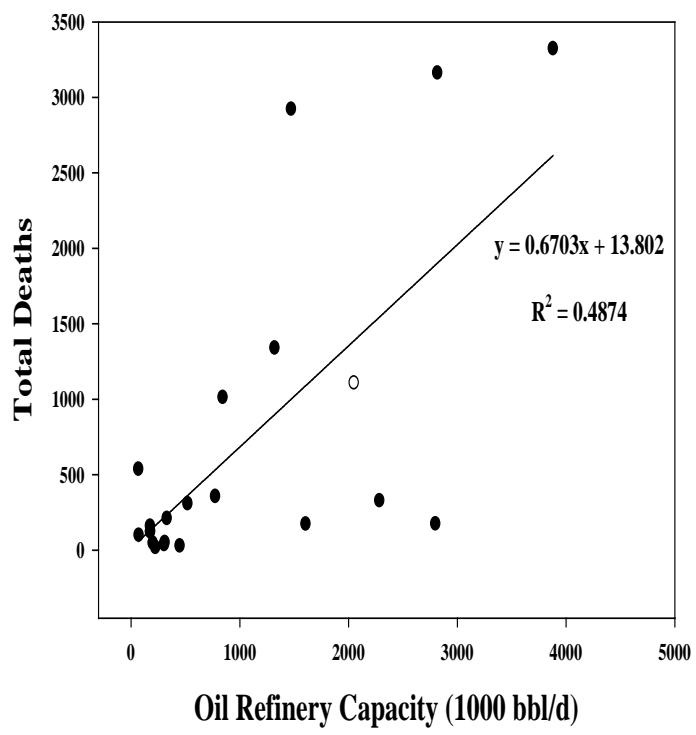

(B)

Figure 8: Linear relations of COVID-19 with oil refinery capacity $(1,000 \mathrm{bbl} / \mathrm{d})$ by the country while $(A) . R^{2}=0.5136$ for the total cases and (B). $R^{2}=0.4874$ for the deaths cases, respectively

\section{i) Cetacean Morbillivirus}

Cetacean morbillivirus (CMV) is a virus that infects dolphins, porpoises, and whales (BARRET, 1999). Large groups of gregarious species found to be the likely reservoirs and sources of CMV infection in susceptible species in the Atlantic and Pacific Oceans (VAN BRESSEM et al., 2014). RNA viruses showed the coronavirus in cetaceans for species of bottlenose dolphin and beluga whale (LEGER et al., 2018). Unusual mortality event linked to CMV has caused death 
in stranded dolphins (GROCH et al., 2018), porpoises, and whales (WVEC, 2017). In the event of an Unusual Mortality Event (UME), there have been humpback whales stranded in the Atlantic Coast (NARK, 2019) and gray whales (OFFICE OF PROTECTED RESOURCES, 2020)) stranding in the Pacific Coast. CMV inoculated and incubated at $37^{\circ} \mathrm{C}$ (WENDY et al., 2018). It is interesting to note that both breeding areas of migratory gray whales in the Pacific Coast and humpback whales in the Atlantic Coast have the same seawater temperature of $29^{\circ} \mathrm{C}$; Baja Peninsula in Mexico from the Pacific Coast and Dominican Republic from the Atlantic Coast of the USA, respectively. As for whale calf breeding, such a temperature of $29^{\circ} \mathrm{C}$ could be appropriate. However, the $29^{\circ} \mathrm{C}$ is too close to the inoculation temperature of $37^{\circ} \mathrm{C}$ (WENDY et al., 2018) for infection by CMV.

Therefore, the situation of such typical breeding areas, from December to April, showed the casualties by the coronavirus as follows: Baja California in Mexicogray whale breeding, had 3,944 cases of the coronavirus (COVID-19), as of May 22, 2020. The Dominican Republic-humpback whale breeding, had 12,725 cases and 434 deaths, as of May 17, 2020. Puerto Rico- humpback whale breeding, had 3,100 cases with 127 deaths, as of May 24, 2020. China might come across the faster emergence of COVID-19 than any other countries such as South Korea, Japan, Italy, and the USA; the latter showed the same COVID-19 with a lag time of one month or so. The humpback and gray whale breeding areas were infected by the coronavirus (COVID-19) in 2020 during the minimum sunspot number. Such infected whales released their evolutionally mutant virus of the coronavirus-infected feces. The transmission of the coronavirus by infected whales continued the spread of the coronavirus on the USA coastline after it had initially appeared in Wuhan in China, which has the highest $\mathrm{CO}_{2}$ emissions in China, during the minimum sunspot number. The coronavirus might not come from China, rather COVID-19 as an evolutionary virus from CMV spread to humans from the multi-sources of 14 humpback whale habitats in Fig. 4 around the world. China has favorable environments for the coronavirus emergence such as sufficient water in 164 lakes, warm weather, highest $\mathrm{CO}_{2}$ emissions, toxic effluents from 4,000 industrial factories, Wenzhou people for toxic leather tannery and textile coloring industry along the Yangtze River, vehicles, and 11 million people in the metropolitan city of Wuhan in China. China produced the highest carbon dioxide emissions in the world (9.8 billion metric tons in 2017). Besides, China used to use banned ozone-depleting chemicals of CFC-11 (RIGBY et al., 2019). These bad Chinese environments facilitated $\mathrm{CO}_{2}$ emissions to induce the increases of the ozone hole area and UV-B radiation for the emergence of the coronavirus (COVID19) pandemic. Humpback whales in 14 habitats in Fig. 4 spread their infected feces to millions of dolphins around the world in Fig. 7. The transmission of COVID19 by cetaceans could explain the initial casualties in China, the USA, Italy, Spain, Iran, Turkey, Brazil, and other countries. Dolphins are one of the primary causes of the coronavirus (COVID-19) pandemic. The feces of dolphins and porpoises transmit the coronavirus (COVID-19) to the people in the USA on the Pacific Coast, including parameters of toxic gases from an oil refinery, power plant, tanning leather textile, vehicle, food waste biogas, and population as; California $(67,917)$, Oregon $(3,228)$, Washington $(17,610)$ and on the Atlantic Coast; Florida $(40,596)$, Georgia $(33,508)$, South Carolina $(7,653)$, North Carolina $(14,939)$, Virginia $(24,081)$, Maryland $(32,587)$, District of Columbia $(6,272)$, Delaware $(6,447)$, New Jersey $(140,008)$, New York $(345,406)$, Connecticut $(33,554)$, Massachusetts $(77,793)$, New Hampshire $(3,071)$, Maine $(1,436)$ with total confirmed cases in parenthesis, as of May 11, 2020. The presence of the migratory whale breeding areas near the USA and migration to feeding areas in the Arctic Sea, through the Pacific Coast (Baja California of Mexico) and Atlantic Coast (Dominican Republic) of the USA, could be why USA had the highest coronavirus (COVID-19) casualty in the world. Also, the USA is also the second-highest country, producing $\mathrm{CO}_{2}$ emissions. Kim (2018) showed that the stranded humpback whale number on the Atlantic coast was proportional to the State of $\mathrm{CO}_{2}$ emissions with linear relation of $\mathrm{R}^{2}=0.6128$ during the years of 2016 to 2018 with the minimum sunspot number in parenthesis as; 2016 (15), 2017 (10), and 2018 (0). It can partly conclude that the humpback whales have already infected by CMV in the breeding areas during the minimum sunspot number. Wuhan environments with water pollutions and millions of migratory birds along with cetaceans might evolutionally transmit CMV to humans as the coronavirus (COVID-19) in Wuhan in China. The coronavirus (COVID-19) could again transmit to cetaceans (porpoises, dolphins, and whales) in the Yangtze River and East Sea. From there, it can spread around the world as shown in Fig. 7 by dolphins.

\section{j) Metropolitan Area Coronavirus Outbreak}

Terrible coronavirus casualties observed in metropolitan areas around the world. $\mathrm{CO}_{2}$ emissions from many people and vehicles, along with many factories and wastewater effluents in the large cities induce a favorable environment for the coronavirus outbreak due to the advanced ozone hole area and UVR. Oil refineries, gas and coal-powered plants, metropolitan waste foods, the textile industry, and the tanning leather industry, produce $\mathrm{CO}_{2}$ gas. Food wastes, oil refineries, natural gas- and coal-powered plants, the tanning leather industry, and vehicle exhaust, produce toxic hydrogen sulfide $\left(\mathrm{H}_{2} \mathrm{~S}\right) . \mathrm{H}_{2} \mathrm{~S}$ is harmful to people in the gas phase (above ten ppm). In the liquid 
phase (3,000 ppm solubility), $\mathrm{H}_{2} \mathrm{~S}$ reacts with iron $(\mathrm{Fe})$ in the water to sediment as $\mathrm{FeS}_{2} / \mathrm{FeS}$ (KIM et al., 2019) so that phytoplankton in the aquatic system is retarded not to convert the dissolved $\mathrm{CO}_{2}$ as pure $\mathrm{O}_{2}$. Therefore, $\mathrm{H}_{2} \mathrm{~S}$ produced from factories in the metropolitan area is polluting the water in the river and drinking water, which caused the coronavirus outbreak. Transmission of the coronavirus through the leather industry via people coming from Wenzhou/Wuhan in China to high $\mathrm{CO}_{2}$ emission countries including Wenzhou-Wuhan in China, Milan in Italy, metropolitan areas of New York City in the USA, Madrid in Spain, Paris in France, Bavaria in Germany, London in the UK, Istanbul in Turkey, Tehran in Iran and Tokyo in Japan. $\mathrm{CO}_{2}$ emissions and $\mathrm{H}_{2} \mathrm{~S}$ gases from people, vehicles, oil refineries, gas or coalpowered plants, factories- leather, tanning, textiles, garments, footwear, and organic dyes, cause the increase of the ozone hole area and UVR in the Earth, leading to the potent virus mutation. It proposed that migratory birds and humpback whales (KIM, 2018) were the carriers of the mutant virus from the Poles to the Continents. Wuhan in China, with a population of 11 million, had the highest $\mathrm{CO}_{2}$ emissions, a large ozone hole area, use of banned ozone-depleting chemicals of CFC-11, high UVR, millions of migratory birds at Dongting Lake, porpoises/ dolphins/ whales at the
Yangtze River and the East Sea, and a tanning-leather industry operated by Wenzhou/ Wuhan Chinese. These could be the primary factors that initiated the coronavirus (COVID-19) pandemic in Wuhan in China.

Bad air $\mathrm{CO}_{2}$ is converted to good air $\mathrm{O}_{2}$ by photosynthesis as shown in Reaction (1). Aerobic microorganism converts $\mathrm{O}_{2}$ to $\mathrm{CO}_{2}$ and get bioenergy (ATP) in Reaction (2). Cyanobacteria in lakes and rivers consume $\mathrm{O}_{2}$, growing cells, and generating $\mathrm{CO}_{2}$ in Reaction (3) for algal blooms (KIM, 2018). If freshwater in the lakes and rivers polluted by tannery effluents, oil refinery make-up water, and agricultural fertilizer enriched water, $\mathrm{O}_{2}$ in the water is converted to $\mathrm{CO}_{2}$ in the water in Reaction (3) and the atmosphere. The enhanced $\mathrm{CO}_{2}$ emissions lead to the increase of the ozone hole area with UV-B radiation, as explained by $\mathrm{NIH}\left(\mathrm{NIH}\right.$, 1989). Such high $\mathrm{CO}_{2}$ emissions and the minimum sunspot number are a good environment for the coronavirus (COVID-19) pandemic. There are air and water pollutions which help induce the coronavirus. Air pollution of $\mathrm{CO}_{2}$ emissions and toxic gases $\left(\mathrm{H}_{2} \mathrm{~S}\right.$, $\mathrm{SO}_{2}, \mathrm{HF}, \mathrm{HCl}$ ) produce from the vehicle exhaust gas, stack gas from oil refineries, flue gas from coal- and gas-powered power plants, food waste, volcanoes, and tanneries. The photosynthesis by chlorophyll-a and microorganism synthesis, are given as follows:

$$
\begin{gathered}
6 \mathrm{CO}_{2}+6 \mathrm{H}_{2} \mathrm{O} \rightarrow \mathrm{C}_{6} \mathrm{H}_{12} \mathrm{O}_{6}+6 \mathrm{O}_{2}-\cdots \\
6 \mathrm{O}_{2}+\mathrm{C}_{6} \mathrm{H}_{12} \mathrm{O}_{6} \rightarrow 6 \mathrm{CO}_{2}+6 \mathrm{H}_{2} \mathrm{O}+38 \mathrm{ATP} \\
\mathrm{C}_{6} \mathrm{H}_{12} \mathrm{O}_{6}+\alpha_{1} \mathrm{O}_{2}+\alpha_{2} \mathrm{NH}_{3} \rightarrow \beta_{1} \mathrm{C}_{4.4} \mathrm{H}_{7.3} \mathrm{~N}_{0.86} \mathrm{O}_{1.2}+\beta_{2} \mathrm{CO}_{2}+\beta_{3} \mathrm{H}_{2} \mathrm{O} \cdots \cdots
\end{gathered}
$$

These processes can have deadly effects on older adults with pulmonary disease in metropolitan areas. Older adults have to move from the metropolitan areas to the urban areas with forests and farmland for fresh air in Reaction (1). Also, water pollution caused by carcinogens, toxic chemicals, chromium complex from tannery effluents, and make-up water from oil refineries can also have an extremely harmful effect on elderly people in metropolitan areas. This air and water pollutions in metropolitan areas could be critical to older adults in huge cities such as New York City, Milan, Paris, London, Tokyo, Tehran, Wuhan as well as other huge cities are especially vulnerable.

k) Vehicles

Vehicle exhaust emissions create when the airfuel mixture burning inside internal combustion engines release carbon dioxide back into the atmosphere causing health problems (AZO CLEANTECH, 2019). A 2013 study by MIT indicates that 53,000 early deaths occur per year in the United States alone because of vehicle emissions (CAIAZZO, 2013). Every day a person inhales 15,000-20,000 liter of air, so even relatively small amounts of any harmful substances, long inhaled with contaminated atmospheric air, adversely affect health, to cause various diseases of the respiratory system, eye, digestion, heart, and blood vessels. Composition of exhaust gases is $\mathrm{N}_{2}, \mathrm{O}_{2}, \mathrm{H}_{2} \mathrm{O}, \mathrm{CO}, \mathrm{CO}_{2}, \mathrm{NO}_{x}, \mathrm{SO}_{2}$, benzene, aldehydes, $\mathrm{O}_{3}$, particular matter (PM) (SKYBRARY, 2019). World vehicles by country in 2015 were available from the International Organization of Motor Vehicle Manufacturers. The information was correlated with coronavirus cases and deaths as of March 29, 2010, and a list of countries and their carbon dioxide emissions. The relationship between vehicle numbers and $\mathrm{CO}_{2}$ emissions showed a linear coefficient of $\mathrm{R}^{2}=0.6313$ to indicate that $\mathrm{CO}_{2}$ emissions were proportional to vehicle numbers. Coronavirus confirmed cases and deaths were also proportional to vehicle numbers as $R^{2}=0.5846$ (Fig. 9A) and $R^{2}=0.4281$ (Fig. $9 \mathrm{~B})$, respectively. It was evident that halting the spread of the coronavirus could be achieved using the following schemes: 1) Use of the electric vehicle rather than gasoline, natural gas, biodiesel, diesel or coal combustion. 2) The elderly should leave large cities for small cities with clean air and water. 


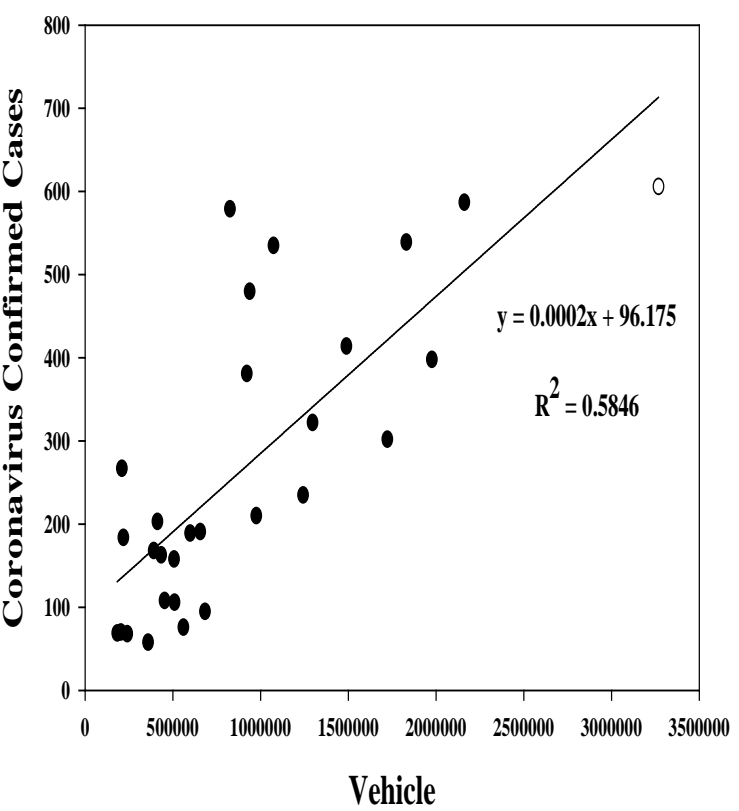

(A)

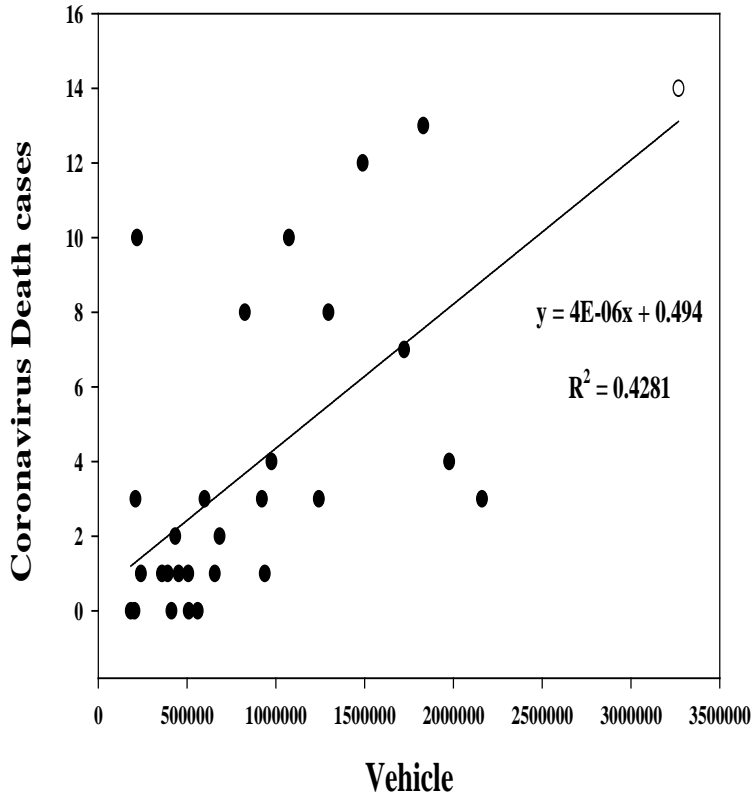

(B)

Figure 9: Vehicle number in each country related with $(A)$. coronavirus confirmed cases $\left(R^{2}=0.5846\right)$ and (B). death cases $\left(R^{2}=0.4281\right)$

\section{I) The Leather Industry}

Leather manufacturing can simplify as; merchant providing hides and skins locally or from importing, pretreatment, tanning (vegetable or chromium), leathering goods, footwear goods (shoemaking), luxurious Gucci handbags, merchant selling and exporting, wastewater treatment of tanneries to cope with environmental regulation. These steps are highly sophisticated and require a lot of experience and knowledge of the tannery leathering industry. Materials from bovine hides and sheep and goat skins use for soles, belts, straps, bags, coats and shoes. The global rank of leather production is as follows; 1. China, 2. Brazil, 3. Italy, 4. Russia, 5. India (BUFFALO JACKSON, 2020). The major chemicals used during leather production are as follows: Pentachlorophenol, di-butyl phthalate, benzyl butyl phthalate, bis (2-Ethylhexyl) phthalate chlorinated paraffin, anthracene (a carcinogen) nonyl phenol, N-methyl pyrrolidone, methyl isothiazolinone (carcinogen, dibutyl tin carcinogen), azo dyes (a carcinogen hexachlorobenzene), chromium (a carcinogen), formaldehyde (a carcinogen), arsenic (a carcinogen), sodium dichromate, cobalt dichloride, cadmium sulfate, lead chromate (DIXIT et al., 2015). Leather chemicals (biocides, surfactants, chromium sulfate, polyurethane resins, sodium bicarbonate, sodium sulfide, formic acid) sell in the US, Mexico, Canada, Italy, Spain, France, Turkey, China, India, Japan, Brazil, Saudi Arabia (GRAND VIEW RESEARCH, 2019). These major leather chemicals suppliers are all the major countries with coronavirus cases. Bovine hide productions in each leather country in 2004 correlated with the total coronavirus cases $\left(R^{2}=0.6922\right)$ and the total coronavirus deaths $\left(R^{2}=0.8514\right)$ in Fig. $10(A)$ and 10(B), respectively, based on data from FAO 2004. In this case was in India, Brazil, Russia, Argentina, Pakistan, Australia, Mexico, Ukraine, Italy, Egypt, Sudan, South Africa and other countries (MEMODOVIC, 2008). The leading exporters of leather footwear are China, Italy, Spain, Germany, USA, Belgium, Portugal, Brazil, Romania, France, Indonesia, and the Netherlands, all of which are the major countries of the coronavirus outbreak. 


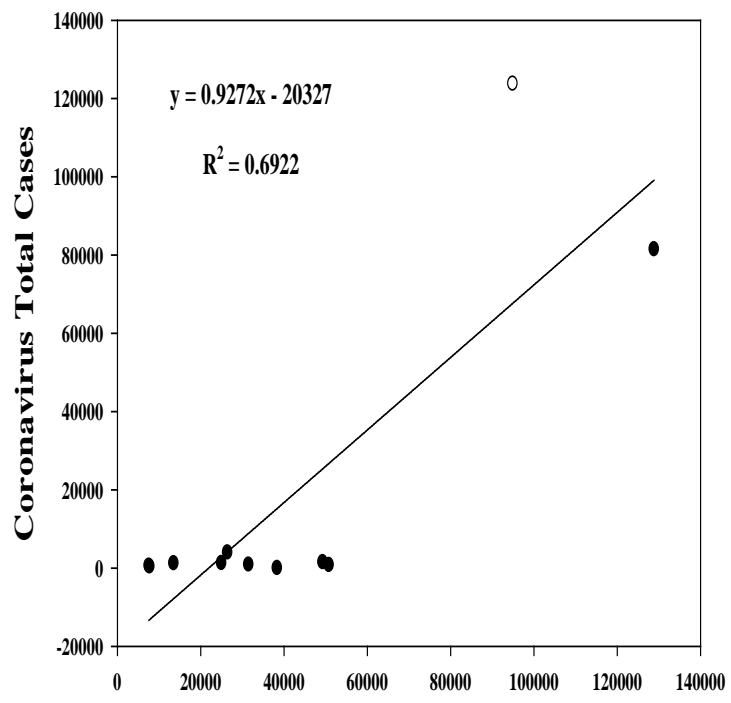

Cattle Hide Production (FA0, 2004)

(A)

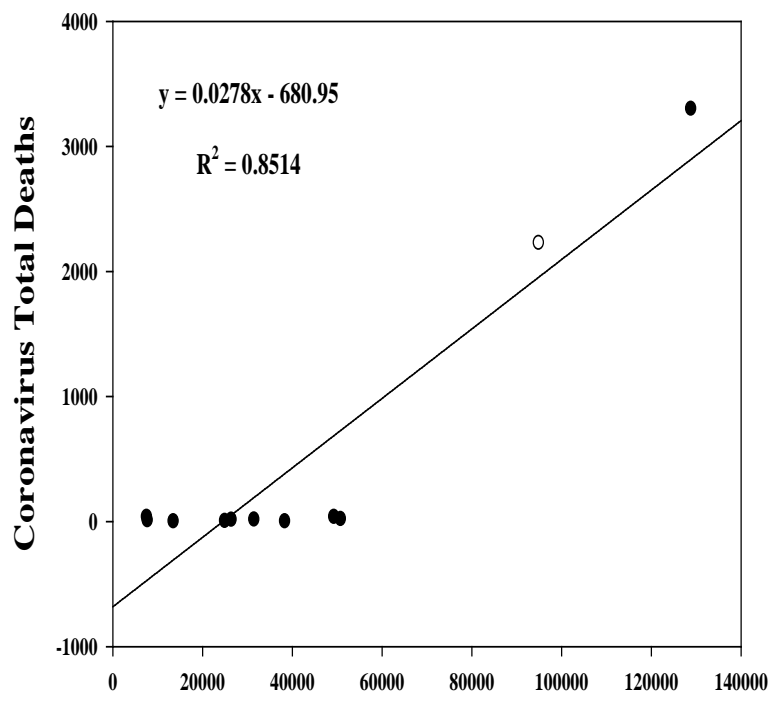

Cattle Hide Production (FA0, 2004)

(B)

Figure 10: (A). Linear relationship of total coronavirus cases $\left(R^{2}=0.6922\right)$ and $(B)$. total deaths $\left(R^{2}=0.8514\right)$ with cattle hide production in each country $(F A O, 2004)$

$65 \%$ of global leather production sources from bovine (cattle), 15\% sheep, 11\% pigs, and 9\% from goats. Most of the leather in the US and Europe comes from China (13), USA (1), Brazil (4), India (11), Argentina (48). European countries exporting leather goods are Italy (6), Spain (3), France (7), Belgium (16), where the numbering in parenthesis implies the rank of global coronavirus cases as of May 20, 2020. All the top 10 countries of the coronavirus outbreak, including Germany (8), Iran (10), UK (5), Switzerland (25), and Turkey (9), are associated with the global leather industry. Since the leather industry uses very toxic chemicals during leather production, its impact is to kill people with carcinogenic and derivatives, having an acute and chronic effect on both water and air. This could be why so many 70-75 year old's were died by the coronavirus ever since 100,000 Chinse immigrants from Wenzhou in China, famous for leather and textile industries, arrived in Prato in Italy in the 1980s and 1990s. Wenzhou people moved to Wuhan, which is the seventh-largest city in China. As for the leather and textile industries, a sufficient supply of water is very critical. The Yangtze River and Han River in Wuhan have deteriorated by Wenzhou people who caused the coronavirus outbreak. They went back to Wenzhou after the coronavirus outbreak in Wuhan in China. They came back to Italy, Europe and the USA to escape from the coronavirus (COVID-19) pandemic. It can conclude that the starting point of the coronavirus outbreak was due to the toxic chemicals used in the leather and textile industries by the Wenzhou people in Wuhan. They have a long history of leather production and shoemaking dating back over 500 years from the Qing Dynasty
(1796-1820) (MURAKAWA, 2006). To prevent further damage by the leather and textile industries, global regulations have to firmly set up to limit the kinds and dosages of chemicals in the leather tannery industry. The number of European leather industry companies in Sweden (4 companies), United Kingdom (22), Germany (50), France (47), Italy (1,309), Spain (113), and Romania (91) showed the linear relationship $\left(R^{2}=\right.$ 0.7826) with coronavirus cases, as of April 9, 2020 as shown in Fig. 11. 


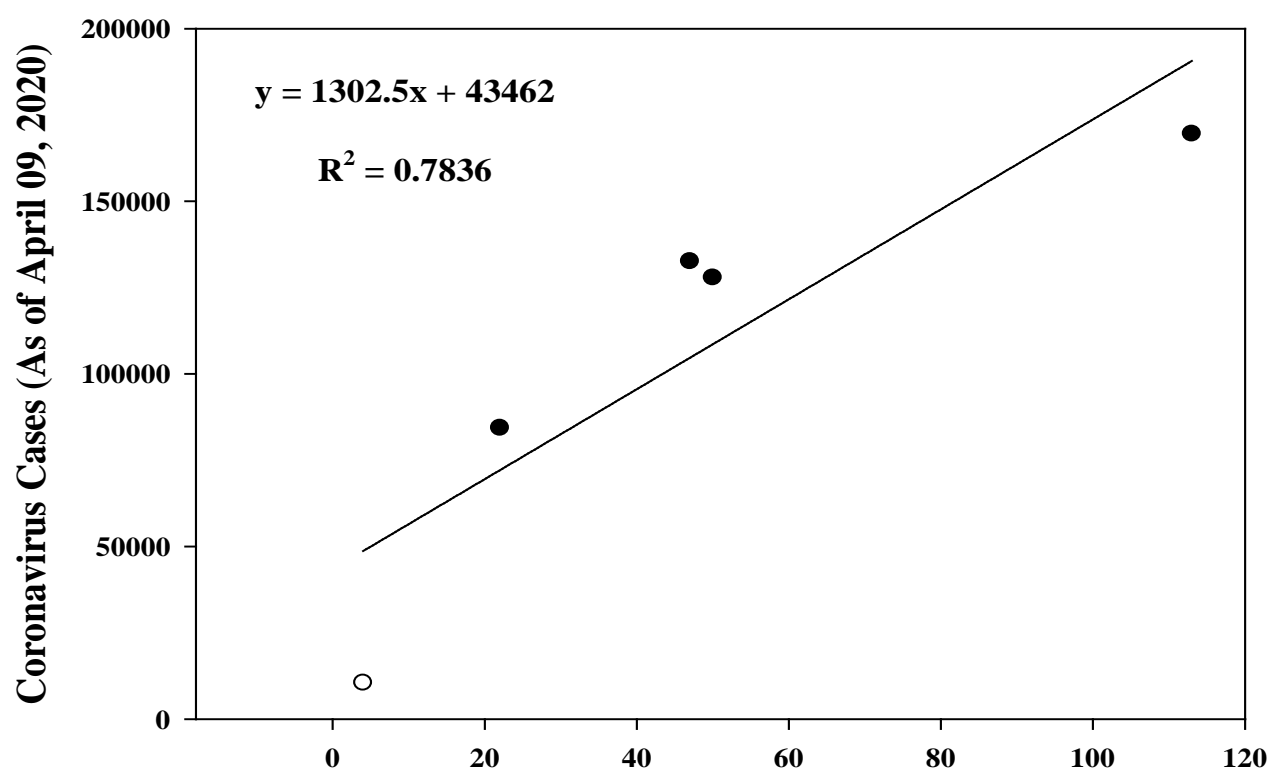

Number of European leather Industry company

Figure 11: Linear relationship $\left(R^{2}=0.7826\right)$ between the number of European leather industry companies and Coronavirus cases as of April 09, 2020

The regional outlook from 2014-2025 was as follows (GRAND VIEW, 2019) while the parenthesized number was the ranking in terms of global coronavirus confirmed cases as of May 5, 2020. Typical tanneries at Fez of Morocco are shown in Fig. 12.

North America; USA (1), Canada (12), Mexico (21), Europe; Italy (3), Spain (2), UK (4) France (5), Germany (6) Turkey (8), Asia Pacific: China (11), Japan (31), India(15), Central and South America; Brazil (9), Ecuador (17), Middle East and Africa; Iran (10), Saudi Arabia (19), Israel (28), South Africa (46). The global organic pigments market includes azo phthalocyanine, quinacridone, and others with application areas of paints and coatings, plastics, inks and other applications. Major market players are located in the United States (1), Canada (12), Germany (6), Belgium (13), Sweden (22), Switzerland (18), Spain (2), Luxembourg (58), Netherlands (16), Czech Republic (45), United Kingdom (4), India (15), Hong Kong (88), China (11), Japan (31), and Singapore (26). The parenthesized numbers are the coronavirus ranking as of May 5, 2020. The chemicals from the leather tanning industry and organic pigments in tannery wastewater caused serious soil and water pollution resulting in dangerous health hazards to both humans and animal life (SAXENA et al., 2016). The chemicals used in the leather industry are pentachlorophenol, dibutyl benzyl butyl phthalate, bis (2-Ethylhexyl phthalate), short-chain, chlorinated paraffin, anthracene, nonylphenol, N-methyl pyrrolidone methyl isothiazolinone, organotin compounds (dibutyltin), which are partly carcinogen and less biodegradable. It is therefore evident that chemicals from the leather industry and organic pigments deteriorate freshwater in rivers and lakes such as Mohawk River; Hudson River (New York), Mississippi River (Minnesota (28), Wisconsin (25), lowa (21), Illinois (4), Missouri (24), Kentucky (35), Tennessee (19), Arkansas (39), Mississippi (27), Louisiana (11), New York (1). Lakes; Erie, Ontario, Oneida, Seneca, Cayuga (New York (1)), Lake Michigan (Wisconsin (25), Illinois (4), Indiana (14), and Michigan (7)). The leather industry in Milwaukee in Wisconsin used to pollute Lake Michigan. Los Angeles River (CA(5)), Colorado River (Colorado (17), Arizona (23), California (5)). The parenthesis numbers are the State rank of the coronavirus cases, as of May 5, 2020. It is necessary to purify the water quality of rivers and lakes from pollutioninduced by tannery wastewater, which ultimately contributed to the catastrophic coronavirus outbreak. Toxic chemicals deteriorate freshwater in rivers and lakes, breaking down the food web cycle in freshwater in Reaction (3). Plankton cannot produce clean oxygen from carbon dioxide by photosynthesis in Reaction (1). Therefore, carbon dioxide $\left(\mathrm{CO}_{2}\right)$ accumulates in the water as well as in the air. Accumulated $\mathrm{CO}_{2}$ induces the increase of the ozone hole area for less ultraviolet absorption by the ozone layer. 


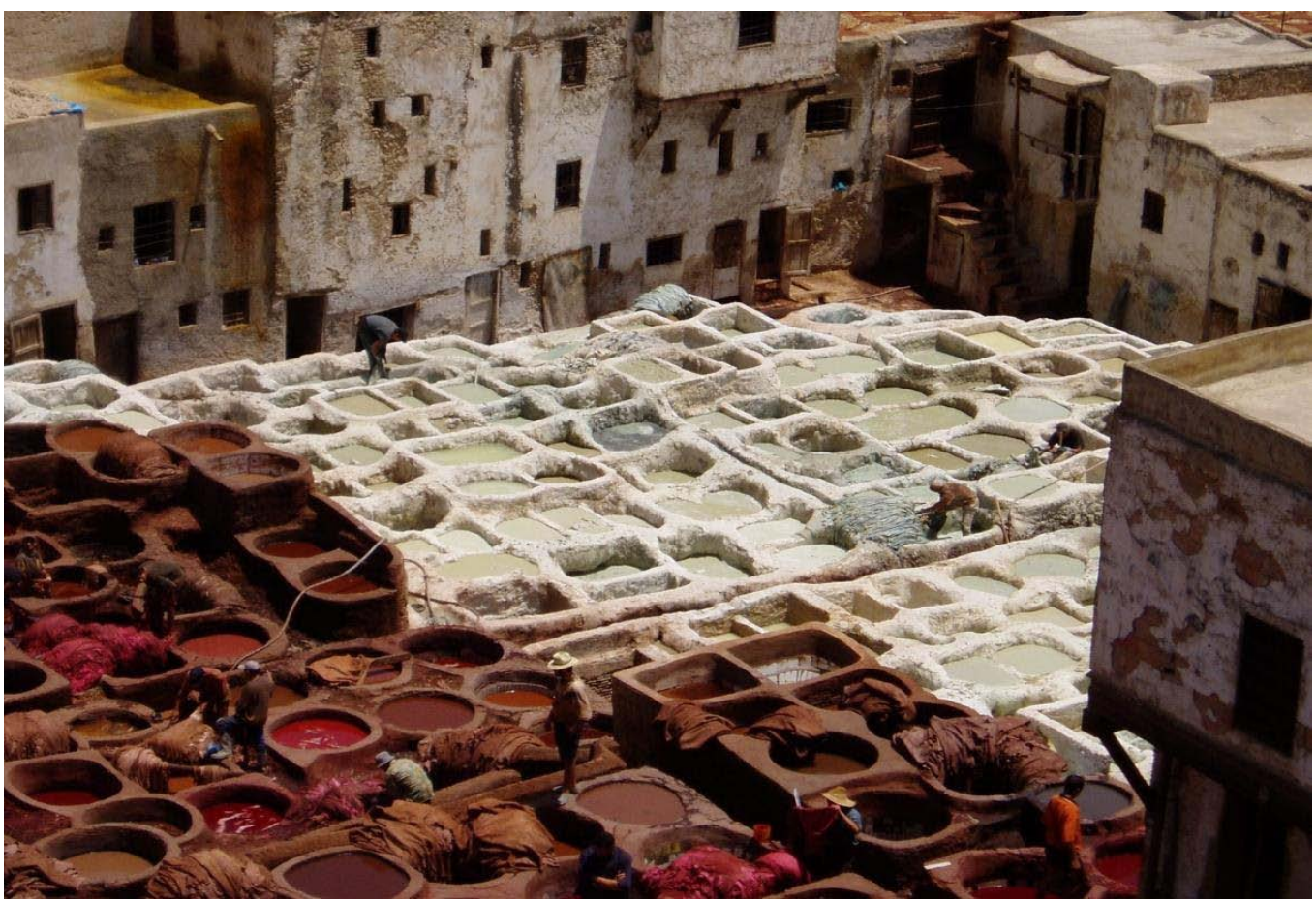

Figure 12: The tanneries at Fez of Morocco produce leathers.

Consequently, ultraviolet radiation becomes strong, which enhances the activity of the coronavirus. To stop the propagation of the coronavirus (accyukon.com March 19, 2020), it is necessary to decrease the number of chemicals in the leather industry and organic pigments as well as clean the water in rivers and lakes; for example, by bioremediation approaches, as suggested by Saxena (2016). In the European leather industry, Italy (71\%) and Spain $(11.1 \%)$ are the two main contributors to the value of production of the sample. Over 1,600 companies with 1,300 tanneries, Italy's share in the sample is $80 \%$. The European leather industry in 2011 was tannery companies 1,783, footwear 11,692 companies, and leather goods 10,710 companies (SOCIAL AND ENVIRONMENT). The countries handling tannery and leather goods are the same, showing a high number of COVID-19 deaths. It can, therefore theorize that toxic chemicals used for the tanning process have polluted the water as well as the air, eventually causing acute and chronic respiratory problems resulting in coronavirus deaths. The toxic chemicals polluted the ecosystem in the rivers and lakes so that normal photosynthesis was no longer possible, and carbon dioxide accumulated in the water as well as in the air. Carbon dioxide emissions are proportional to coronavirus cases. Upper rivers deteriorate by tannery chemicals to cause the coronavirus casualties, as were at the Yangtze River in Wuhan, China, the Po River in Milan in Italy, and the Hudson River in New York City in the USA. One key factor of the coronavirus outbreak is that the tanning leather industries are spread all around the world. Chromium is used in about $90 \%$ of tanning operations worldwide. Tanneries are so toxic that $95 \%$ of the US tanneries have moved overseas. India has minimal regulations to use 69,000 tons of chrome salts annually in 1,600 Indian tanneries. Typical chrome pollution countries had coronavirus deaths as follows: India (3,303), Indonesia (1,242), Pakistan (985), Colombia (613) and Bangladesh (386), as of May 20, 2202, and Hubei in China $(3,212)$, as of May 5, 2020, as shown in global chromium pollution from tanneries for 95 sites (https://leathersustainability.weebly.com/). There is the global chromium pollution from tanneries in South America (Guatemala, Columbia, Uruguay), Africa (Niger, Kenya, Tanzania, Ethiopia), Asia (India, Bangladesh, Indonesia, China) deaths.

m) Leather Dyes

Leather dyes are non-water-soluble dyes (sulfur dyes) and soluble dyes (anionic acid dyes, atmospheric metal complex dyes, triphenyl (methane dyes)). Benzene uses as an emulsifier. China and India are emerging international leather players with high pollution levels. The leather color processes by dyeing the leather with dyes and pigmentation by aniline dye while azo dyes are very harmful to health (LEATHER DIRECTIONARY). China is the world's largest leather producer in shoes, clothing, bags, and luggage. Leather for the car industry comes from Brazil (22\%), Mexico (15\%), China (13\%), Argentina (10\%) and Austria (5\%), while Mexico (28\%), China and Italy (14\%), Austria (8\%), Germany, South Korea, South Africa and the United Kingdom (4\%) for finished leather (LEATHER INDUSTRY, 2015). 53.5\% of final products using leather as footwear are produced by the USA, Switzerland, and 
Germany, while $8.2 \%$ of automotive leather goods produce by the USA, Japan, Germany, and France. $38.3 \%$ of luggage and goods are manufactured in all of the above countries. Dyes alter the color of textiles and leather. Europe is one of the most important markets from colorants (28\% in 2019). The key countries with major dye markets are the UK, France, Spain, Germany, Italy, Russia, Sweden, Denmark, Switzerland, Netherlands, Turkey, Czech Republic (EUROPE DYES MARKET, 2019). Since tannery leather and textile industries use very harmful chemicals and carcinogens, every country with such industries is now confronting the high death rate of the coronavirus outbreak. The rank of the coronavirus (COVID-19) pandemic was as follow: UK 5, France 7, Spain 3, Germany 8, Italy 6, Russia 2, Sweden 24, Denmark 44, Switzerland 25, Netherlands 20, Turkey 9, and Czech Republic 49, as of May 20, 2020. It is very much certain that organic dyes altering the color of textiles and leather are the most critical parameters causing the coronavirus (COVID-19) pandemic.

\section{n) Footwear Industry}

Global leather production countries are as follows with deaths in parenthesis, as of April 11, 2020). Algeria (561), Argentina (393), Australia (100), Canada (5,912), Bangladesh (386), Brazil $(17,983)$, Chile (509), China $(4,634)$, Egypt $(659)$, Ethiopia $(5)$, India $(3,303)$, Japan (768), Kenya (50), South Korea (263), Morocco (194), Nepal (-), Nigeria (192), Mexico (5,666), New Zealand (21), Malaysia (114), Pakistan (985), Paraguay (11), Philippines (842), Germany $(8,193)$, Indonesia $(1,242)$, Russia (2,972), South Africa (312), Taiwan (7), Tanzania (21), Tunisia (47), Ukraine (564), Thailand (56), USA (93,558), Uruguay (20), Vietnam (-), Zimbabwe (4). Most of the countries producing leather had a significant number of coronavirus deaths, although there were minor exceptions. The $\mathrm{NIH}$ lists 246 hazardous chemicals associated with leather processing. Groundwater near tanneries showed the presence of sulfuric acid, arsenic, chromium, lead, and zinc, while toxic gases like ammonia, hydrogen sulfide, and carcinogenic arylamines emit from tanneries. Hexavalent chromium is a carcinogen, whose long-term effects include lung cancer, impaired immune system, and reproductive problems.

\section{PREVEnTION}

\section{a) Volcanic Regions}

The volcanic gas $\left(\mathrm{H}_{2} \mathrm{O}, \mathrm{CO}_{2}, \mathrm{SO}_{2}, \mathrm{CO}, \mathrm{H}_{2} \mathrm{~S}, \mathrm{HCl}\right.$, $\mathrm{HF}$ ) inhibits the activity of the coronavirus carried by some microorganisms due to the toxicity and the acidity of volcanic gases. As of May 20, 2020, there were reported coronavirus cases (deaths) in the volcanic countries as follows: Peru 99,483 (2,914), Chile 49,579 (509), Ecuador 34,151 (2,839), Columbia 16,935 (613), Costa Rica 882 (10), El Salvador 1,571 (31), Guatemala
2,133 (43), Honduras 2,955 (147), Nicaragua 254 (17), Mexico 54,346 (5,666), Panama 9,867 (281), Kuwait 17,568 (124), Bahrain 7,532 (12), Saudi Arabia 59,854 (329), Qatar 37,097 (16), UAE 25,063 (227), Indonesia 19,189 (1,242), Japan 16,367 (768), Taiwan 440 (7), Oman 6,043 (28), DR Congo 1,731 (61), Iceland 1,802 (10), Greenland 11 (0), Philippines 13,221 (842), New Zealand 1,503 (21). South American countries with active volcanoes showed minimal deaths: Costa Rica 882 (10), El Salvador 1,571 (31), Guatemala 2,133 (43) while other countries such as Peru, Chile, Ecuador, Columbia, Honduras, Mexico, and Panama produced hides to export leather to the USA, Europe, and China, leading to excessive outbreaks of the coronavirus. Middle Eastern countries with active volcanoes and oil refineries had a lower amount of deaths. There is, however, tanned and dressed leather production in Saudi Arabia, at the same time the UAE spent on luxury leather goods with toxic chemicals as preservatives, which could be why there were more casualties in such countries than other volcanic countries including additional parameters of oil refineries, gas-powered power plants, and dolphins. Japan and Indonesia have 130 and 127 active volcanoes, respectively. Indonesia is an exporter of leather raw material to the world, while Japan has good technology in the dyeing and textile industry. Their volcanic gas inhibitions were not sufficient to block the toxic chemical hazards induced by the tannery leather industry including additional parameters of oil refineries, gas-powered power plants, and dolphins for the coronavirus outbreak.

\section{b) Preventive Measures}

The following locations can be asylum from the coronavirus (COVID-19) pandemic.

\section{i. Tropical latitudes of $20^{\circ}$}

Since the ozone concentration is low in the tropical area, UV-B radiation is strong enough to protect people from the coronavirus

\section{ii. Active Volcanoes}

Volcanic gases during eruptions contain very toxic components such as $\mathrm{SO}_{2}, \mathrm{CO}, \mathrm{H}_{2} \mathrm{~S}, \mathrm{HCl}, \mathrm{HF}$, and $\mathrm{CO}_{2}$. However, when volcanoes are not in eruptive mode, minor gases are continuously released enough to protect people from the coronavirus. Indonesia is located at the equator $\left(0^{\circ}\right)$, with 127 active volcanoes. Since Indonesia is one of the major manufacturers of leather with its tanneries, there could be more casualties in Indonesia, even though it locates on the equator with many active volcanoes. Japan has 130 active volcanoes. Japan is famous for the leather-textile industry, leading to the coronavirus outbreak. Japan might have fewer cases and casualties due to the presence of volcanoes. The same principle applies to Iceland (10), New Zealand (21), Guatemala (43), El Salvador (31), Greenland (0), Nicaragua (17), Papua New Guinea (0). 


\section{iii. Artificial Volcanic Gases}

The major toxic volcanic gases are $\mathrm{SO}_{2}$ and $\mathrm{H}_{2} \mathrm{~S}$. A small number of such gases can be prepared artificially by heating sulfur (S) powder over burning charcoal to produce $\mathrm{SO}_{2}$ gas. Decomposed food waste produces $\mathrm{H}_{2} \mathrm{~S}$ gas in an ambient condition by microorganisms. Any of these two gases of $\mathrm{SO}_{2}$ and $\mathrm{H}_{2} \mathrm{~S}$ can be spread once a week at a low level of $1 \mathrm{ppm}$ to protect people from the coronavirus outbreak.

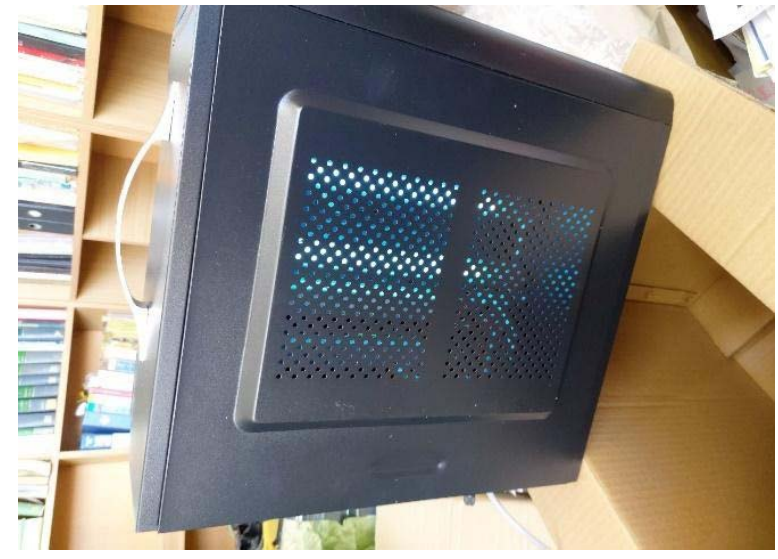

(A) iv. UV-B Radiation

UV-B radiation is the most simple, safe, cheap, and efficient method to kill the coronavirus itself. A portable UV-B radiator (Fig. 13) was used with two 50Watt UVB lamps in an office while six other large sizes 50-watt UVB lamps were used in 500 chickens cage for more than a year to kill $100 \%$ of the virus within 50 minutes (KIM, 2019).

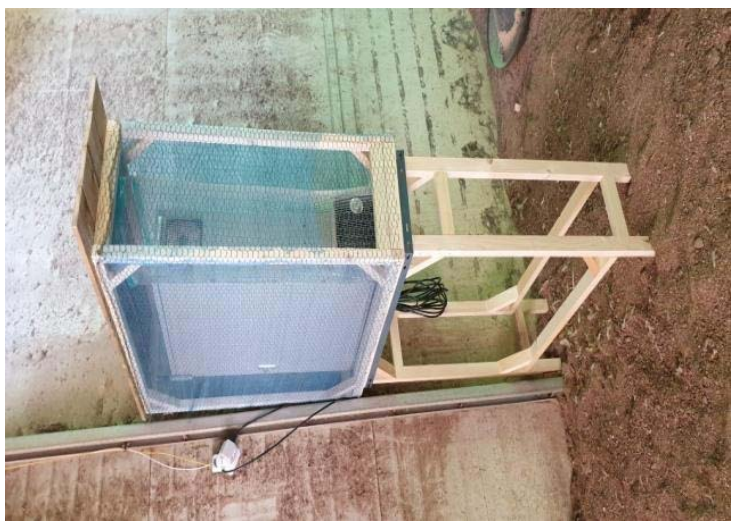

(B)

Figure 13: (A) Portable UV-B radiator. (B) Pilot Scale UV-B radiator, killing 100\% of the virus within 50 minutes by six 50W UV-B lamps (KIM, 2019). A and B have been run at the indoor working office and an outdoor 500 chickens cage for more than a year, respectively

\section{v. Warm and Humid Environment}

The virus is not active at temperatures above $55^{\circ} \mathrm{C}$ and relative humidity above $40 \%$ (Kim, 2018) with a heater, humidifier, and UV-B radiator installed together to expel the coronavirus.

vi. Curcumin

India has 3 major areas for tanneries. India's far lower rate of 3,303 deaths, as of May 20, 2020, could be caused by their daily food intake of curcumin. Curcumin has shown to exhibit antioxidant, anti-inflammatory, antiviral properties (AGGARWAL et al., 2007), which might help people not to contact the coronavirus. Eating Indian curcumin as often as possible, is recommended to protect the pulmonary alveolus from the coronavirus attack.

\section{vii. Vegetable Tanning and Natural Chemicals}

Most of the coronavirus outbreak occurred in 213 countries and territories associated with a tannery, leather, footwear, textiles, and garment industries, spreading through human contact from Wenzhou to Wuhan in China, Milan in Italy and Europe, and eventually in New York City in the USA. It suggests to use vegetable tanning, not the chromium salts, for safe tanning.

\section{viii. Green Zone}

Forestry, farmland, and clean lakes and rivers provide phytoplankton, chlorophyll-a photosynthesis, converting harmful air of $\mathrm{CO}_{2}$ to good air of $\mathrm{O}_{2}$ during sunlight. Since the coronavirus is inhibited by the fresh oxygen produced in Reaction (1) for reduction of $\mathrm{CO}_{2}$, the green zone is essential in the metropolitan area.

\section{c) Total Ozone and Latitude}

The ozone in the stratosphere absorbs a large part of the Sun's biologically harmful ultraviolet radiation. The ozone layer resides in the stratosphere and surrounds the entire Earth. UV-B radiation (280-315 nm wavelength) (www.esrl.noaa.gov/csl) from the Sun is strongly absorbed, so that the amount of UV-B radiating on the Earth's surface is significantly reduced.

The total ozone at any location on the globe is defined as the sum of all the ozone in the atmosphere directly above that location. Total ozone varies strongly with latitude over the globe, with the large values occurring at middle and high latitudes during all seasons. The values of total ozone are the lowest in the tropics in all seasons because the thickness of the ozone layer is smallest there (www.theozonehole.com/ twenty.htm), with little variation of the total ozone in the tropics $\left(20^{\circ} \mathrm{N}-20^{\circ} \mathrm{S}\right.$ latitudes) leading to high ultraviolet-B radiation, creating a safe zone from the coronavirus outbreak. Countries are listed below in the order of global deaths caused by the coronavirus, as of May 20, 2020, with country latitude in parenthesis.

17,983 Brazil (11), 1,242 Indonesia (6), 2,839 Ecuador (2), 3,303 India (21), 5,666 Mexico (19), 842 Philippines (14), 2,914 Peru (10), 441 Dominican 
Republic (18), 281 Panama (9), 114 Malaysia (3), 56 Thailand (15), 51 Burkina Faso (12), 147 Honduras (15), 61 Democratic Republic of Congo (4), 189 Bolivia (17), 140 Cameroon (6), 55 Niger (18), 10 Mauritius (20), 10 Venezuela (5), 8 Trinidad and Tobago (10), 22 Singapore (1), 192 Nigeria (10), 9 Sri Lanka (7), 50 Kenya (0), 53 Mali (17), 31 Ghana (10), 31 El Salvador (13), 10 Guyana (5), 15 Republic of Congo (0), 23 Liberia (6), 7 Barbados (13), 9 Jamaica (18), 10 Costa
Rica (10), 28 Oman (23), 28 Ivory Coast (7), 43 Guatemala (14), 12 Togo (8), 5 Ethiopia (9), 21 Tanzania (-7), 4 Zimbabwe (20), 30 Senegal (14), 7 Zambia (-13), 22 Haiti (19), 3 Antigua and Barbuda (17), 3 Angola (12), 111 Sudan (15), 2 Belize (17), 7 Djibouti (11), 1 Brunei (4), 12 Gabon (1), which are all located in the tropics $\left(20^{\circ} \mathrm{N}-20^{\circ} \mathrm{S}\right.$ latitude). Their locations seem relatively safe compared to other countries between the tropics and the Polar region.

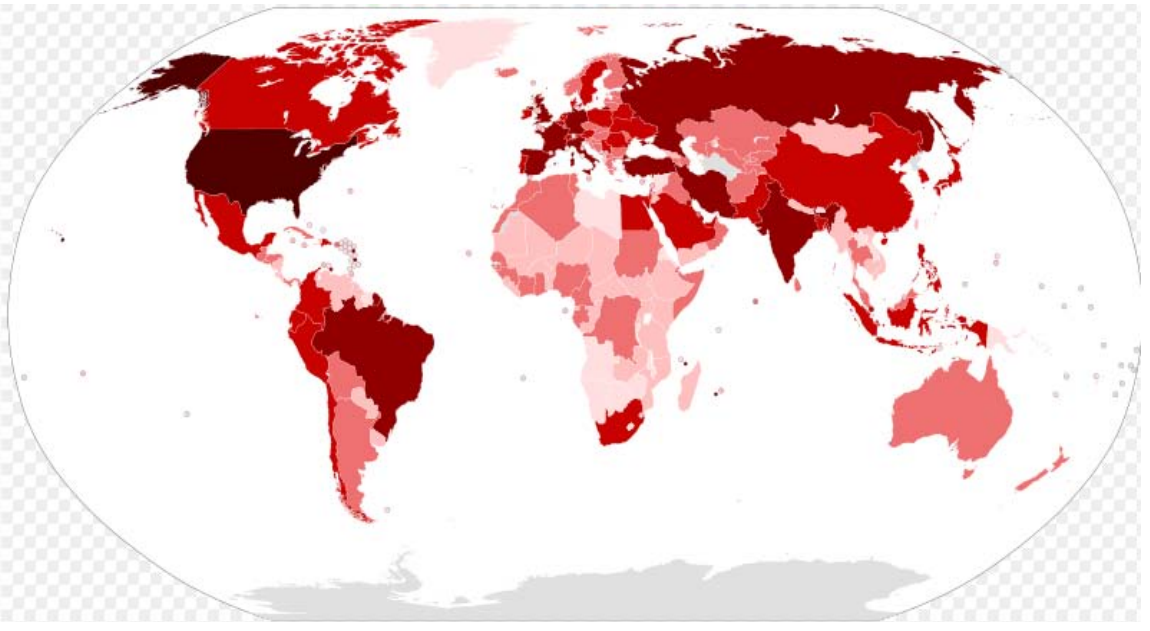

(A) (H1N1) Pandemic in 2009

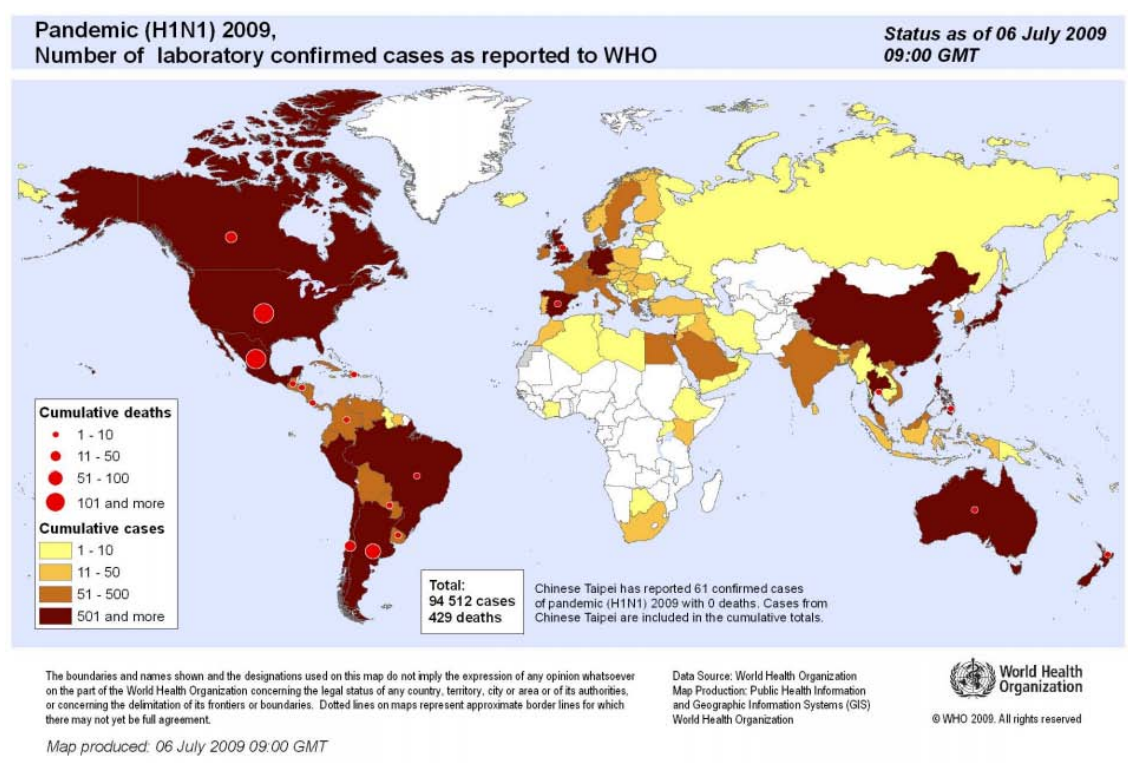

(B) Coronavirus (COVID-19) Outbreak World Map

Figure 14: Global distribution maps of: (A). H1N1 pandemic with 284,000 deaths in 2009.

(B). Coronavirus (COVID-19) pandemic with 380,630 deaths, as of June 02, 2020

The first pandemic caused 284,000 deaths (Fig. $14 \mathrm{~A})$. It occurred in the form of the 2009 swine flu virus H1N1, coming from both pigs and birds and then transmitted readily to and among humans. The second pandemic was in 2020 in the form of the coronavirus (COVID-19) with high deaths of 380,630 as of June 02 , 2020. Those pandemics both happened during the minimum sunspot number with an 11-year cyclic pattern. Fig. Fourteen showed that the global distributions between $\mathrm{H} 1 \mathrm{~N} 1$ in 2009 (Fig. $14 \mathrm{~A}$ ) and coronavirus (COVID-19) in 2020 (Fig. 14 B) were very similar to each other. Since there have been H1N1 human casualties in 2009, a future pandemic can expect in 2031 when the sunspot number reaches its minimum. 
The minimum sunspot number allows the excessive UV$B$ radiation on the Earth $(\mathrm{NIH}, 1989)$ for simple mutation of viruses. If global $\mathrm{CO}_{2}$ emissions reduce, the ozone hole areas will also decrease, leading to reduced UV-B radiation on the Earth, with fewer chances of virus mutation. Therefore, it is essential to reduce $\mathrm{CO}_{2}$ emissions globally to prevent a new pandemic in 2031. $\mathrm{CO}_{2}$ emissions can reduce in leather-tannery chemicals, from chrome salts to natural tannins, coal- and gaspower plants to nuclear plants, vehicles from gasoline to electric, iron fertilization in oceans, forestry, and farming.

\section{d) Vaccine and Medication Development}

A vaccine is simple but hard to be developed quickly in efficacy. Since most biological species have natural enemies, such new viruses can block by preexisting vaccines or natural enemies. However, this provides partial and incomplete protection, at best. The virus behavior before the potent solar UV-B mutation during the minimum sunspot number can be monitored in the Arctic and in the Antarctic before the beginning of the migration of birds and humpback whales from the Poles to the Continents. Virus, bacteria, phytoplankton, and krill are food web cycles for penguins, migrating birds, and humpback whales. Once the mutant virus generates by the strong UV-B in the Poles, it is impossible to stop the natural transmission of mutant virus to transmitters from birds and whales, and ultimately to humans and cetaceans in the Continents, as happened in the 2020 coronavirus (COVID-19) pandemic. The reduction of $\mathrm{CO}_{2}$ emissions in the Continents allows the low UV-B radiation in the Poles with a less and weak outbreak of mutant virus due to the decreased ozone hole area (KIM, 2019). Phytoplankton grows beneath the iceberg during the winter of the Poles, which is fed by krill. When phytoplankton is not sufficient enough, krill eats its own body so that the body weight is shrinking. To keep krill healthy enough not infected by mutant virus, a few artificial schemes of phytoplankton supply can attempt at the habitat of Adélie penguins, a vital part of the Antarctic food chain eating krill, in the Antarctic Peninsula. Firstly, phytoplankton blooms are artificially induced during the autumn or early winter in 2029, 2030, and 2031 till 2032 using algal blooming technology proposed by Kim (2018 and 2020) for algal blooms. Secondly, phytoplankton grown by biotechnology above the iceberg, before sea ice melted by climate change, is supplied into the seawater to feed krill and minimize the infection of krill by the mutant virus, generated during the minimum sunspot number (from 2030 to 2032). Such weak mutant virus infecting krill, penguin, migratory birds, and humpback whales can low pathogenically transmit to the Continents in China and USA, located at high $\mathrm{CO}_{2}$ emissions and middle latitudes with less UV-B radiation. Such schemes may allow us to avoid the terrible pandemic as experienced in 2020.

\section{e) Phenomena of Coming Pandemic in 2031}

There were over 130 dead dolphins that were stranded on a beach in Cape Verde (Site number 2 of humpback whale habitat in Fig. 4) near the Canary Islands in West Africa on September 28, 2019 (WARD, 2019).

The ozone hole reached its peak on September 8 and then shrank (NASA, 2019). UV-B radiation also reached its peak. Furthermore, the minimum sunspot number allows the strong radiation $(\mathrm{NIH}, 1989)$. Therefore, UV-B radiation is the most powerful during the 11-year cycle of the sunspot number from 2019 to 2020. The highest UV-B radiation on the Poles caused the strongest mutation to cetaceans for CeMV. Humpback whales have 14 common habitat districts segments (NOAA, 2015) including Baja California (Site number 5) and the West Indies (Site number 1 in Fig. 4), with the coasts of the USA, as well as Cape Verde in West Africa, on the migratory routes between 14 breeding habitats and feeding areas of the Poles in Fig. 4. It is most likely that humpback whales, infected by CMV, migrated to the 14 habitats on the Continents, including the USA (Site 1 and 5), China (Site 3) and Cape Verde (Site 2). Infected humpback whales release their CMV-infected feces which are consumed by dolphins so that dolphins in the USA, China, Cape Verde in West Africa and Europe, were infected by CMV and died of pneumonia.

Kim (2019) proposed that the coronavirus (COVID-19) initiated by the stallholders for wet meat of stranded porpoises. The present study, however, suggests that there were 14 starting points of the coronavirus (COVID-19) by the 14 habitat districts (Fig. 4) of the humpback whales (1. West Indies, 2. Cape Verde, 3. China, 4. Hawaii, 5. Mexico, 6. Central America, 7. Brazil, 8. Gabon, 9. Madagascar, 10. Western Australia, 11. Eastern Australia, 12. Oceania, 13. Southeastern Pacific, 14. Arabian Sea). The sudden spread of the coronavirus can cause by the 14 worldwide habitats of humpback whales (Fig. 4) and a wide range of dolphins (Fig. 7) as well as the leather tanning industry (Fig. 12).

On the other hand, Wuhan in China has plenty of water in the Yangtze River and Dongting Lake for migratory birds and cetaceans with warm ambient temperatures. Wuhan is one of the highest $\mathrm{CO}_{2}$ emitting cities with polluted water. These environments around Wuhan caused the powerful UV-B radiation for the evolutionary mutation from the CMV in cetaceans to the human coronavirus (COVID-19). Chinese people from Wuhan/Wenzhou can be responsible for spreading the toxic leather tanning dye industry around the world, which is one of the significant parameters for the coronavirus outbreak. China should decrease $\mathrm{CO}_{2}$ 
emissions as well as water pollution by the elimination toxic chromium salts from the leather tanning industry. More than 130 dead dolphins in Cape Verde in September of 2019 (WARD, 2019) could be the preventive phenomena for the coronavirus outbreak in Wuhan at the end of December 2019, with at least three months lag time. The coming third pandemic in 2031 can prepare in advance by monitoring the 14 habitats in the humpback whale districts, as happened in 130 dead dolphins in Cape Verde in September of 2019 (WARD, 2019). The third pandemic of low pathogenic virus disease may initiate either from China or from the USA in the year of 2031, spreading all around the world either by birds, pigs, and humans (H1N1, USA, 2009) or by cetaceans and humans (COVID-19, China, 2020). Vaccines or medication, such as Tamiflu or Relenza, can be developed during years from 2029 to 2030 with virus samples collected at the Alaska of the Arctic and the Antarctic Peninsula of the Antarctic with the warmest areas by the potent UV-B radiation.

\section{Conclusion}

Parameters spreading the coronavirus around the world in 213 countries and territories with 6,302,999 coronavirus cases and 375,559 deaths as of June 02 , 2020 were investigated. The areas were leather tanning and processing, oil refineries, gas- and coal-powered plants, total ozone and the ozone hole, skin cancer rate, vehicles, population, carbon dioxide emissions, volcanic regions, migratory birds-humpback whales districts, dolphins, and preventive means, including vaccine development and phenomena of coming the third pandemic in 2031. Hydrogen sulfide $\left(\mathrm{H}_{2} \mathrm{~S}\right)$ produces during the processes of the tannery, leather, footwear, textiles, and garment industries, decomposed microorganisms in the metropolitan area, flue gas in the natural gas- or coal-powered plants, stack gas in oil refineries and volcanic gas. Hydrogen sulfide is very toxic, causing pulmonary disease resulting in death and retarding the phytoplankton growth. The appropriate iron fertilization experiment suggests to maximize the availability of dissolved iron ( $\mathrm{Fe}$ ) to phytoplankton for maximal $\mathrm{CO}_{2}$ consumption by diatoms. There is little variation in total ozone throughout the seasons resulting UV-B radiation acting as a shield, leading to the inhibition of coronavirus activity in the safe tropics area. The coronavirus (COVID-19) casualties can reduce by proper strength UV-B radiation, which can be varied from the low latitude of the equator to the high latitude of the Poles. $\mathrm{CO}_{2}$ emissions produced by coal-and-gaspowered power plants, oil refineries, vehicle exhaust gas, metropolitan food waste gas, human exhalation, the leather-tannery industry, and the dye industry. On the other hand, $\mathrm{CO}_{2}$ can minimally consume by the forest and the farmland. Global $\mathrm{CO}_{2}$ emissions were correlated with the total cases $\left(R^{2}=0.6693\right)$ and deaths
$\left(R^{2}=0.7081\right.$. European $\mathrm{CO}_{2}$ emissions were correlated with total cases $\left(R^{2}=0.6142\right)$ and with deaths $\left(R^{2}=0.4763\right)$. USA State $\mathrm{CO}_{2}$ emissions were correlated with total cases $\left(R^{2}=0.6065\right)$ and with deaths $\left(R^{2}=0.4401\right)$. USA State oil refinery capacity producing $\mathrm{CO}_{2}$ gases in stack gas was correlated with total cases $\left(R^{2}=0.4003\right)$ and with deaths $\left(R^{2}=0.6413\right)$. The global vehicle number producing $\mathrm{CO}_{2}$ exhaust gases was correlated with total cases $\left(R^{2}=0.6068\right)$ and with deaths $\left(\mathrm{R}^{2}=0.6313\right)$. Global population number producing $\mathrm{CO}_{2}$ gases as human exhaling gas was correlated with total cases $\left(R^{2}=0.6373\right)$ and with deaths $\left(R^{2}=0.4642\right) . \mathrm{CO}_{2}$ emissions from various sources have increased the UV$\mathrm{B}$ radiation on Earth. The sunspot number from 1979 to 2019 was reversely proportional to the ozone hole area (million $\mathrm{km}^{2}$ ) with $\mathrm{R}^{2}=0.2668$. It is important to monitor the sunspot number, especially when approaching the period of minimum sunspot number, to prepare for the effects of another cyclic minimum sunspot number in 2031. It expects that serious outbreaks of viruses occur in 2020 plus 11 years later of 2031 as the third pandemic via either humans, birds, cetaceans, pigs, or other species. Cetaceans such as humpback whale/dolphin/porpoise were proposed as the initial transmitters of 2012 MERS-CoV stranded in the Persian Gulf coast in Saudi Arabia as well as of the 2020 coronavirus (COVID-19) stranded in the Yangtze River in China, respectively. Migratory flyways of wild bird overlap with the routes of migratory humpback whales to suggest that AIV may be transmitted, not only by commonly known migratory birds flyways, but also by humpback whales habitats. Dolphins cover most of the seawater in the world, which agrees well with results that there were sudden increases in global coronavirus cases. It postulates that cetaceans, including whales, dolphins, and porpoises transmit the globe with the coronavirus (COVID-19) pandemic in over 213 countries and territories. The humpback and gray whale breeding areas were infected by the coronavirus (COVID-19) in 2020 during the minimum sunspot number. Such infected whales released their evolutionally mutant virus of the coronavirus-infected feces, leading to the spread of the coronavirus on the US coastline after it had originally appeared in Wuhan in China. The coronavirus might not come from China, rather COVID-19 as an evolutionary virus from CMV spread to humans from the multi-sources of 14 humpback whale habitats around the world. China having good environments for the coronavirus outbreak, such as rich water, warm weather, highest $\mathrm{CO}_{2}$ emissions, 4,000 industrial factories, Wenzhou people for toxic leather tannery and textile coloring, might allow the earliest emergence of the coronavirus in China among 14 humpback whales districts. Transmission of the coronavirus through the leather industry via people coming from Wenzhou/Wuhan in China to high $\mathrm{CO}_{2}$ emission countries including Milan in Italy, metropolitan areas of 
New York City in the USA, Madrid in Spain, Paris in France, Bavaria in Germany, London in the UK, Istanbul in Turkey, Tehran in Iran and Tokyo in Japan. $\mathrm{CO}_{2}$ emissions and $\mathrm{H}_{2} \mathrm{~S}$ gases from people, vehicles, oil refineries, gas- or coal-powered plants, factoriesleather, tanning, textiles, garments, footwear, and organic dyes, cause the increase of the ozone hole area and UV-B radiation (UVR) in the Earth, leading to the increase of virus mutation for the coronavirus. Coronavirus confirmed cases and deaths were linear to vehicle numbers as $R^{2}=0.5846$ and $R^{2}=0.4281$, respectively. Total coronavirus cases by country were linearly proportional to oil refinery capacity by country as $R^{2}=0.5136$ for the total cases and $R^{2}=0.4874$ for the deaths, respectively. Major leather chemicals suppliers are all the major countries with coronavirus cases. Bovine hide productions in each leather country were correlated with the total coronavirus cases $\left(R^{2}=0.6922\right)$ and the total coronavirus deaths $\left(R^{2}=0.8514\right)$, respectively. Carbon dioxide emissions are proportional to coronavirus cases. Upper rivers deteriorate by tannery chemicals to cause the coronavirus casualties, as were at the Yangtze River in Wuhan, China, the Po River in Milan in Italy, and the Hudson River in New York City. The values of total ozone are the lowest in the tropics in all seasons because the thickness of the ozone layer is smallest there (www.theozonehole.com/ twenty.htm), with little variation of the total ozone in the tropics ( $20^{\circ} \mathrm{N}-20^{\circ} \mathrm{S}$ latitudes) leading to high ultraviolet-B radiation, creating a safe zone from the coronavirus outbreak. The UV-B radiation is the most simple, safe, cheap and efficient method to kill the coronavirus itself. The virus is not active at temperatures above $55^{\circ} \mathrm{C}$ and relative humidity of above $40 \%$ with a heater, humidifier, and UV-B radiator installed together to expel the coronavirus. Consuming Indian curcumin as often as possible is recommended to protect the pulmonary alveolus from the coronavirus attack. Organic dyes altering the color of textiles and leather, are the most critical parameters causing the coronavirus. The number of European leather industry companies in Sweden, the United Kingdom, Germany, France, Italy, Spain, and Romania showed the linear relationship $\left(R^{2}=0.7826\right)$ with coronavirus cases. UV-B radiation is the strongest during the 11-year cycle of the sunspot number from 2019 to 2020. The highest UV-B radiation on the Poles caused the strongest mutation to cetaceans for CMV. Humpback whales have 14 common habitat districts segments including Baja California (Site 5) and the West Indies (Site 1), with the coasts of the USA, as well as Cape Verde in West Africa, on the migratory routes between 14 breeding habitats and feeding areas of the Poles. Humpback whales, infected by CMV, migrated to the 14 habitats on the Continents, including the USA (Site 1 and 5), China (Site 3) and Cape Verde (Site 2) for West Africa and Europe. Infected humpback whales release their CeMV-infected feces, which are consumed by dolphins so that dolphins in the USA, China, Cape Verde in West Africa and Europe, were infected by CMV and died of pneumonia. The present study suggests that there were 14 starting points of the coronavirus (COVID-19) by the 14 habitat districts of the humpback whales (1. West Indies, 2. Cape Verde, 3. China, 4. Hawaii, 5. Mexico, 6. Central America, 7. Brazil, 8. Gabon, 9. Madagascar, 10. Western Australia, 11. Eastern Australia, 12. Oceania, 13. Southeastern Pacific, 14. Arabian Sea). The sudden spread of the coronavirus could cause by the simultaneous transmission of COVID-19 from 14 worldwide habitats of humpback whales, linked to millions of dolphins as well as the global leather tanning industry. The third pandemic of low pathogenic virus disease may be initiated either from China or from the USA in the year of 2031, spreading all around the world either by birds, pigs, and humans (H1N1, USA, 2009) or by cetaceans and humans (COVID-19, China, 2020). Vaccines or medication, such as Tamiflu or Relenza, can be developed during years from 2029 to 2030 with virus samples collected at the Alaska of the Arctic and the Antarctic Peninsula of the Antarctic with the warmest areas by the strong UV-B radiation. The preventive phenomena for the third pandemic in 2031 can be monitored at 14 habitats in the humpback whale districts, as happened in 130 dead dolphins in Cape Verde in September of 2019, at least three months earlier than COVID-19 in Wuhan in China. UV-B radiation is the most simple, safe, cheap, and efficient method to kill the coronavirus itself.

\section{ACKNOWLEDGMENT}

The author expresses sincere gratitude to the University of Suwon, Ware Valley, and G-Land of South Korea for their financial supports. Editing and typing works undertaken by Professor Jonathan Wright are also greatly appreciated.

\section{References Références Referencias}

1. Aggarwal B B et al (2007). Curcumin: the Indian solid gold. The molecular targets and therapeutic uses of curcumin in health and disease. Springer: 1-75.

2. Azo Cleantech (2019). What are vehicle exhaust emissions? Clean Tech 101. 19 $9^{\text {th }}$ of August 2019.

3. Baker S, Frias L, Bendi A (2020). The coronavirus (COVID-19). CDC Business Insider.

4. Bienfang P K, Harrison P J (1984). Sinking rate response of natural assemblages of temperate and subtropical phytoplankton to nutrient depletion. Marine Biology. 83: 293-300.

5. Bloomberg (2020). Mapping the coronavirus outbreak across the world. June 2, 2020.

6. Buffalo Jackson (2020). Which countries produce the most leather 2020? 2020 Buffalo Trading Company. 
7. Caiazzo F, Ashok A, Watz I A, Yim S H L, Barret S R $H$ (2013). Air pollution and early deaths in the United States. Part I. Quantifying the impact of major sectors in 2005. Atmospheric Environment. 79: 198-208.

8. Dixit S, Yadv A, Dwivedi P D, Das M (2015). Toxic hazards of leather industry and technologies to combat threat: A review. Journal Clean. Produc. 87: 39-49.

9. Eldridge $L$ (2019). Function and Disorders of the Alveoli. Verywell health. Retrieved from https://www. verywellhealth.com/what-are-alveoli-2249043.

10. Europe dyes market (2019). Industry Newsletter. 8759. 180.

11. Grand View Research (2019). Global leather chemicals market size. Industry Report 2019-2025.

12. Gray E, Stein T. (2019). Ozone hole is the smallest on record since its discovery. NASA. October 22, 2019.

13. Groch K R, Santos-Neto E B, Diaz J, Ikeda J (2018). Guiana dolphin unusual mortality event linked to cetacean morbillivirus, Brazil. Emerging Infectious Diseases. 24: doi: 10.3201/eid2407.180139.

14. Hathaway D H (2010). The Solar Cycle. Living Reviews in Solar Physics. 7. 1. https://doi.org/ 10.12942/Irsp-2010-1.

15. International whaling commission. Bottlenose dolphin.

16. Jefferson $T$ A, Webber $M A$, Pitman $R L$ (2015). Marine mammals of the world: A comprehensive guide to their identification, $2^{\text {nd }}$ ed. Elsevier, San Diego, CA.

17. Kim T J (2018). Prevention of avian influenza virus by ultraviolet radiation and prediction of outbreak by satellite parameters. Journal of Biomedical Science and Engineering. 11: 182-206.

18. Kim T J (2018). Transmission of avian influenza virus by humpback whale and its stranding along the Atlantic Coast with $\mathrm{CO}_{2}$ emissions. Journal of Biomedical Science and Engineering. 11: 359-381.

19. Kim T J (2018). Prevention of harmful algal blooms by control of growth parameters. Advances in Bioscience and Biotechnology. 9: 613-648.

20. Kim T J, Hong G H, Kim D G, Baskaran M (2019). Iron fertilization with enhanced phytoplankton productivity under minimal sulfur compounds and grazing control analysis in HNLC region. American Journal of Climate Change. 8: 14-39.

21. Kim T J (2019). Spanish flu, SARS, MERS-CoV by $\mathrm{CO}_{2}$ emission and maximal sunspot number. Journal of Biomedical Science and Engineering. 12: $53-75$.

22. Kim T J (2019). Transmission and prevention of Wuhan coronavirus disease 2019 (COVID-19) during minimum sunspot number. Global Journal of Medical Research: F Disease. 20 (3): 13-33.
23. Kim $T J$ (2020). Appropriate location and deployment method for successful iron fertilization. Open Journal of Marine Science. in press.

24. Memodovic O, Mattile H (2008). The global leather value chain: the industries, the main actors and prospects for upgrading in LDCs. Internal Journal of Technological Learning. Innovation and Development I. 482-519.

25. Murakawa T (2006). The geography and history of industrial clusters in Zhejiang province. China.

26. Nark J (2019). Whales are dying along East Coastand scientists are racing to understand why. National Geographic. Retrieved from https://www. nationalgeographic.com/animals/2019/03/humpbac k-whales-unusual-mortality-event/

27. National Institutes of Health (1989). Sunlight, UV radiation, and the skin. NIH Consensus Statement. May 8-2010. 7(8): 1-29.

28. National Oceanic and Atmospheric Administration (NOAA) Fisheries (2015). Humpback whale (Megaptera novaeangliae). April 21, 2015. www.nmfs.noaa.gov/pr.

29. NOAA Fisheries. Common bottlenose dolphin overviews.fisheries.noaa.gov.

30. Office of Protected Resources (12-Feb. 2020). 20192020 gray whale unusual mortality event along the West Coast. NOAA Fisheries. Retrieved from https://www.fisheries.noaa.gov/national/marine-lifedistress/2019-2020-gray-whale-unusual-mortalityevent-along-west-coast.

31. Otts L E (1963). Water requirements of the petroleum refining industry. US Department of the Interior. U.S. Governmental Office.

32. Rigby M (2019). Increase in CFC-11 emissions from eastern China based on atmospheric observations. Nature. 569: 546-550.

33. Saxena G, Bharava RN (2016). Organic pollutants in tannery wastewater and bioremediation approaches for environmental safety. Chapter 4: 115-119.

34. Ward A (2019). Over 100 dead dolphins found stranded on beach. World News. Animals. LAD BIBLE.

35. Wendy K J, Jochen K, Ludlow M (2018). Evolutionary evidence for multi-host transmission of cetacean morbillivirus. Emerging Microbes \& Infections. 7: 201

36. WVEC Staff (2017). High numbers of humpback whales dying off Atlantic Coast. WUSA9. April 26. 2017.

37. Yoon S W, Webby R J, Webster R G (2014). Evolution and ecology of influenza viruses. Curr. Top. Microbiol. Immunol. 385: 359-375. 